\title{
DEFICIT ATTENTION DISORDER: \\ Partisan-Motivated Reasoning About Government Overspending
}

\author{
John V. Kane \\ Assistant Professor \\ New York University \\ john.kane@nyu.edu \\ Ian G. Anson \\ Assistant Professor \\ University of Maryland, Baltimore County \\ iganson@umbc.edu
}

Word Count: 11,761 


\begin{abstract}
Government overspending remains a prominent concern in American politics. Yet, despite the burgeoning literature on partisan-motivated reasoning (PMR), we know little about the extent to which such concern arises from partisan considerations. We advance extant literature by uncovering a novel means by which citizens reason about deficits in a partisan-motivated fashion-i.e., by shifting the importance of the issue. Leveraging pre-registered experimental and observational studies, we find that partisans systematically adjust the importance of government overspending based upon which party occupies the presidency. Further, this proclivity to engage in PMR does not require explicit cues from elites, is symmetrical across parties, and appears to function both to protect one's own party and rebuke the opposing party. Lastly, in a large-scale text analysis of transcripts from televised partisan media, we again find strong evidence of PMR on the issue of government overspending, though primarily in conservative media.
\end{abstract}


"George [W.] Bush's policies have taken us from a projected \$5.6 trillion surplus at the end of the Clinton administration to massive deficits and nearly \$4 trillion in new debt today."

-- Democratic Presidential Candidate Barack Obama (2008)

"We're a debtor nation... We've got to get rid of the \$19 trillion in debt."

--Republican Presidential Candidate Donald Trump (2016) ${ }^{1}$

The success of any policy depends, at least in part, upon a nation's willingness and ability to finance it. Regardless of the policy domain, one of the foremost debates surrounding any major piece of legislation in the United States is whether "we can afford it." From tax cuts to social welfare programs, military deployments to environmental protection, the federal budget looms large in political discourse (e.g., Fisher 2012; Morgan 2009). For example, we regularly observe invocations of the Congressional Budget Office's (CBO) estimated costs of various policies to American taxpayers, ${ }^{2}$ and, in times of economic crisis, so-called "austerity" measures are commonplace and inextricably rooted in concerns about government overspending (e.g., Streeck and Schäfer 2013). Presidential administrations that oversee increases in deficit spending incur substantial criticism for it (e.g., Morgan 2009), and members of the public commonly cite deficits (and the debt that accumulates from repeated deficits) as one of the top priorities in American politics (Newport 2013; Pew Research Center 2016).

Yet, to what extent might concern about government overspending increase not because of objective trends in deficit and debt levels, but because of partisan-motivated reasoning (PMR)? A wealth of scholarship demonstrates that partisans reason about political matters in a "directional" fashion, reinforcing attitudes that are congenial to their preferred political party and/or antagonistic

\footnotetext{
${ }^{1}$ See The New York Times (2008) and Kessler (2016), respectively.

${ }^{2}$ For example, the CBO's Fiscal Year 2018 projection (released in 2017) included dire warnings about the proposed Tax Cuts and Jobs Act of that year.
} 
toward their non-preferred party (Bullock and Lenz 2019; Flynn, Nyhan, and Reifler 2017; Lodge and Taber 2013). In the realm of government overspending, extant research on PMR has largely focused on how so-called partisan "perceptual screens" shape perceptions of the size of budget deficits (e.g., Achen and Bartels; Bullock et al. 2015; Meirick 2016.) PMR may also lead citizens to vary how they attribute blame for deficits and debt, which is consistent with how PMR operates for other economic issues (e.g., Rudolph 2003; 2006).

In this study, we propose a third avenue by which citizens engage in PMR about U.S. government overspending — that is, by adjusting the importance of deficits and debt as a political issue. We premise this argument on the notion that, in contrast to "positional" issues, government overspending more closely resembles a "valence" issue (e.g., Stokes 1963). In other words, overspending will, all else equal, tend to be viewed negatively by most Americans. It follows that partisans are unlikely to change their position on government overspending (i.e., being for rather than against it; Lewis-Beck et al. 2008, 195). And, because deficits originate in the realm of federal policymaking, such negative connotations of overspending likely render it a political liability for a presiding administration. Therefore, periods of increased attention to deficits stand to harm a president's—and thus a party's—-political standing.

Given the "facts" of budget deficits (e.g., their existence, size, and/or growth over time, etc.), as well as the president's perceived accountability for deficit spending (Morgan 2009), we therefore hypothesize that "bias will find a way" (Bisgaard 2015) in the form of changes in perceived importance of government overspending in accordance with which party presides over it (i.e., via the presidency). Specifically, partisans should display greater concern for deficits, and thus be more inclined to prioritize deficit reduction, when an out-party (versus in-party) president occupies the White House. Given that government debt has come to represent an increasingly large 
share of U.S. Gross Domestic Product (see Figure A1 below), this hypothesis stands in notable contrast to a more naïve, yet theoretically plausible, expectation wherein, as deficit spending continues (and, consequently, federal government debt accumulates), partisans in both parties become increasingly concerned about deficits and deficit reduction.

To investigate the extent to which Americans' concern about government overspending is guided by partisan motivations, we pursued three analytical strategies. First, we present the results of two survey experiments that directly manipulate the degree to which Republican (versus Democratic) presidents have presided over deficit spending. Next, we leverage two separate observational data sets, one of which includes repeated cross-sections straddling the end of the Obama presidency and the start of the Trump presidency, and the other involving panel data across three waves ranging from 2016 to 2019. Finally, we explore the existence of PMR in partisan media via a large-scale automated text analysis, as well as a manual content analysis, of popular partisan televised media that spanned the Obama and Trump presidencies.

In each of these analyses, we find strong evidence of PMR, with partisans attaching greater importance to deficits when an out-party (versus in-party) president holds office. Notably, the results of our experiments demonstrate that these effects can occur even in the absence of explicit cues from partisan elites. Further, we find the effects to be surprisingly symmetrical across parties, and that two distinct PMR mechanisms - one defensive (in-party protection) and one offensive (out-party criticism) _ operate in tandem to produce these effects.

In the observational analyses, we find strong evidence that adherents of both major parties rapidly adjusted their perceived importance of deficit spending once Republican Donald Trump assumed the presidency from his predecessor, Democrat Barack Obama. In our exploratory analyses of media attention to government overspending during the Obama and Trump 
presidencies, we do find a notable partisan asymmetry, however. Conservative news media (i.e., Hannity on Fox News) exhibited a substantially stronger tendency to discuss overspending during an outparty (versus inparty) administration than did liberal news media (i.e., The Rachel Maddow Show on MSNBC). Thus, while fiscal responsibility and limited government have long been a purported pillar of conservatism (e.g., Feldman and Zaller 1992), we find that Republicans are no less likely to engage in motivated reasoning than Democrats, even partisan media do not discuss overspending in a symmetrical fashion across party lines.

Our study speaks to an issue that fundamentally determines what government can, and cannot, accomplish. Despite the centrality of deficit spending for American government and political discourse, research on the extent to which citizens are concerned about government overspending has been limited. We contribute to this literature by uncovering a proclivity to engage in PMR on government overspending, and without the aid of explicit cues from partisan elites. Further, by assessing the role of partisanship on the issue of deficit spending, our study contributes to the growing literature on the relationship between partisanship and policy attitudes (Barber and Pope 2019; Mason 2015), with important implications for democratic accountability. Finally, by highlighting the regularity of government overspending and conceptualizing it as a valence, rather than a positional, issue, our study offers novel insights into how partisans engage in PMR, as well as how government deficits can function as a perennial source of political ammunition for parties out of power.

\section{GOVERNMENT DEFICITS: HISTORY AND IMPORTANCE}

Except for a brief period during the presidency of Andrew Jackson, the United States government has been in debt (Smith 2011). The national debt increases to the extent that the federal government runs deficits, which represent the federal government outlaying more dollars than it 
receives in revenues in a given fiscal year. Since the 1970s, the federal government has run a deficit nearly every single year. ${ }^{3}$ Though the federal government may forego paying down the debt for many years (if at all), in a more immediate sense, larger amounts of debt mean a larger share of the federal budget being dedicated to paying the interest on that debt. Such fiduciary obligations stand to limit the kinds of other public policies (e.g., social spending programs, subsidies, tax breaks, etc.; see Wood 2004) that could be enacted insofar as, at least in the short term, such policies will further expand the deficit.

Consequently, federal deficits have been a persistent point of contention in contemporary American political discourse. Debates over major legislative initiatives (e.g., a "Green New Deal", "Medicare for All", and the "Tax Cuts and Jobs Act" of 2017) routinely invoke budgetary costs and projected impact on future fiscal health (e.g., see Levitan 2019; Liu and Eibner 2019; Tankersley, Kaplan, and Rappeport 2017), while debates over "raising the debt ceiling" have become a recurring feature of American politics (Dennis 2019; Mann and Ornstein 2013). In the wake of the Great Recession, "austerity" programs were proposed in direct response to concerns about the growth of the federal deficit (Krugman 2019; Streeck and Schäfer 2013). The parties' national platforms highlight related concerns, with the 2016 Democratic platform explicitly promising that, if enacted, their policies would not "add to the debt", and the 2016 Republican platform stressing the need for a "balanced budget amendment" to "prevent deficits from mounting

\footnotetext{
${ }^{3}$ These years were FY1998-FY2001 during the Clinton presidency. In fact, we find that, since 1973, the average annual deficit as a share of gross domestic product (GDP) is virtually identical for Republican and Democratic administrations (see Figure A1).
} 
to government default." ${ }^{4}$ Further, deficits and debt impose constraints upon presidential agendas (Crosby and Holbrook 2019; Morgan 2009), and presidents of both parties face pressures to discuss the deficit and national debt in public statements (Fisher 2012; Wood 2004). In Congress, requiring a "balanced budget" has been, by far, the most frequently proposed amendment to the U.S. Constitution since 1999 (Desilver 2018). And among members of the public, "the budget deficit" has long ranked among the public's top policy priorities (Meirick 2016; Pew Research Center 2019; see also Gruszczynski 2020). In a study of public support for a balanced budget amendment between 1978-2014, authors Crosby and Holbrook (2019) find that support has ranged from 60 to nearly 90 percent.

As the federal budget is very much a statement about the "appropriate size and purpose of national government” (Morgan 2009, 7), stated concern about deficits appear particular prominent among contemporary Republicans. For example, Republican citizens demonstrate considerably greater support for a balanced budget amendment to the Constitution-which would generally prevent federal expenditures from exceeding existing resources in any given year-than do Democrats (Crosby and Holbrook 2019). Indeed, a foundational component of conservative political ideology is that of fiscal responsibility, wherein the government restrains its size and

4 The 2016 Democratic Party Platform can be found at: https://www.presidency.ucsb. edu/documents/2016-democratic-party-platform. The 2016 Republican Party Platform can be found at: https://www.presidency.ucsb.edu/documents/2016-republican-party-platform (Accessed June 20, 2020). 
scope to limit inefficiencies in the market and/or to avoid "crowding out" private-sector investment (e.g., Feldman 1988; Grossmann and Hopkins 2016, 75-77; Lewis-Beck et al. 2008, 208-9). ${ }^{5}$

\section{DEBT AND DEFICITS AS A VALENCE ISSUE}

Yet, even if Republicans potentially demonstrate more concern about deficits and debt than do Democrats (on average), it is unlikely that members of the public-regardless of party affiliation — generally desire larger deficits. Rather, most Americans likely view smaller deficits to be preferable to larger ones. In a similar vein, presidents avoid discussing the deficit when its growth accelerates, and will reference the deficit more when it shrinks, during their administrations (Wood 2004). No elected officials, in other words, are expected to claim credit for a larger deficit. For these reasons, we regard the size of the deficit (and government debt in general) as a valence issue, and one that uniquely originates from the sphere of policymaking. Unlike "position issues", a valence issue - such as crime or corruption, for example-is, in and of itself, viewed overwhelmingly negatively (or positively), with policy disagreement largely stemming from particulars concerning how to address it rather than whether there should be less or more of it (e.g., Ansolabehere and Snyder 2000; Lewis-Beck et al. 2008, 195; Stokes 1963). ${ }^{6}$

\footnotetext{
${ }^{5}$ One way to restrict the capabilities of government is to disallow tax rate increases. On this point, major Republican candidates are well-known for pledging to do exactly this (Ball 2017; Kroft 2012).

${ }^{6}$ Of course, these perceptions gloss over the many nuanced economic debates on the subject. Questions regarding the deficit—e.g., "how big is too big?" and "exactly when are deficits bad?" (e.g., see Heilbroner and Bernstein 1989; Krugman 2000) - are likely overlooked by the average voter. Further
} 
Thus, despite complexities in the process of government budgeting and the meaning of budget deficits, (Crosby and Holbrook 2019), most voters may simply regard growing deficits as a signal of poor presidential performance. Presidents, for example, are legally responsible for proposing a budget to Congress (Fisher 2012; Morgan 2009), and, as with various other macroeconomic outcomes, presidents are likely to be the ones ultimately held accountable for federal deficits (e.g., Kane 2016; Newman 2013; Sirin and Villalobos 2011). Thus, insofar as government overspending is generally regarded in a self-evidently negative fashion, we contend that (1) citizens are unlikely to change their position on it (i.e., they will not cite larger deficits as a presidential accomplishment), and consequently (2) deficits will function as a political liability for presidents and their respective parties. Such consequences for each party's status and reputation, we argue, provide a fertile foundation upon which partisans may reason about the importance of deficits in a politically motivated fashion.

\section{PARTISAN-MOTIVATED REASONING}

A wealth of existing literature demonstrates a substantial role for partisanship in determining citizens' attitudes about various political issues (Barber and Pope 2019; Cohen 2003; Kinder and Kalmoe 2017; Mason 2015). Barber and Pope (2019), for example, find substantial changes in partisans' support for a broad range of policies (e.g., a minimum wage increase) depending upon whether President Trump (purportedly) supports or opposes the policy. Such studies of partisanmotivated reasoning (PMR) have also sought to articulate when, where, and why Americans disagree on economic facts. Early efforts asserted that evaluations of economic reality diverge due

complicating matters, there are a variety of ways in which deficits can be analyzed (e.g., as raw dollar amounts, as inflation-adjusted dollar amounts, as a percent of federal spending, or as a percent of GDP). 
to the filtering effects of a partisan "perceptual screen" (e.g., Bartels 2002; Campbell et al. 1960). More recent work in political psychology has sketched out a more nuanced theory of partisan bias. Specifically, citizens balance a need to express partisan-motivated judgments against a desire to accurately evaluate current conditions (e.g., Bolsen, Druckman, and Cook 2014; Leeper and Slothuus 2014).

These rival goals - accuracy and in-party bias - compete in the minds of partisans to produce over-time variation in the extent and direction of partisans' perceptual gaps about objective reality (Bisgaard 2015; Dickerson and Ondercin 2017; Jerit and Barabas 2012). ${ }^{7}$ Much of the literature on this phenomenon has specifically analyzed partisans' retrospective economic evaluations (REEs), or overall views on recent economic performance (e.g. De Geus 2019; Gerber and Huber 2009; Jones 2019). REEs generally assess views of whether the economy has gotten "better" or "worse" in recent times.

How might PMR shape public attitudes toward deficit spending? As highlighted above, partisans can draw different conclusions about objective conditions. Indeed, existing public opinion research on government overspending has largely focused on gaps in Americans' beliefs about the deficit's size (Achen and Bartels 2016; Bullock et al. 2015). Kinder and Kalmoe (2017, 112-13), for example, find that, despite the fact that the federal deficit had substantially decreased in size between 1992 and 1996, Republicans were far more likely than Democrats to erroneously state that the size of the deficit had increased during this time. Similarly, Meirick (2016) finds that

\footnotetext{
${ }^{7}$ Another important theoretical debate centers on the difference between 'insincere, expressive' partisan cheerleading and 'true' gaps in partisans' knowledge of current conditions (see Bullock and Lenz (2019) for a review).
} 
Republicans were significantly more likely than Democrats to believe that the budget deficit had decreased during (Republican) President George W. Bush's tenure (2001-08). Such biased perceptions of the deficit, therefore, systematically relate to citizens' and the president's party identification, and are clearly consistent with the notion of a partisan "perceptual screen".

Beyond a "perceptual screen", the extant evidence also suggests that partisans may make complex rationalizations to defend their 'preferred-world' view of current affairs (Kunda 1990; Parker-Stephen 2013). Specifically, partisans may interpret economic conditions correctly, yet engage in PMR when attributing credit and blame (Rudolph 2006). In doing so, they develop effortful justifications to defend their preferred partisan incumbents from accusations of economic mismanagement. For example, partisans might acknowledge that the budget deficit is ballooning under an in-party president, yet lay blame for the development elsewhere (e.g., Congress, international factors, the out-party's obstructionism, etc.). This "second face" of motivated reasoning about economic matters can meaningfully interfere with attempts at retrospective political accountability (Bisgaard 2019; Evans and Pickup 2010).

Building directly upon this literature, we argue that PMR likely extends beyond misperception of "the facts" and/or motivated attribution of responsibility. Representing a third opportunity to engage in PMR, partisans likely adjust the importance with which they assign issues related to government deficits and debt. Put differently, even if partisans loosely agree on the basic facts of the deficit (its size and growth over time), and behave similarly in terms of how they attribute responsibility for those facts to political figures (e.g., the president, the president's party, etc.), they may nevertheless be motivated to adjust concern about the issue itself. In practice, this would mean that when partisans are aware of a growing federal deficit, for example, and view an in-party 
president to be accountable for it, they can nevertheless satisfy partisan instincts by placing less importance on the deficit as an issue.

Compared to the multitude of studies on misperceptions of facts, a far smaller number have examined partisan-motivated reasoning and perceived issue importance (e.g., Boninger, Krosnick, and Berent 1995; Mullinix 2016; Slothuus and de Vreese 2010). None of these existing studies has investigated perceived importance of deficit spending in the U.S. case in particular. One notable quasi-experimental study by Bisgaard and Slothuus (2018) leveraged a unique five-wave Danish panel survey from 2010-2011. The authors show how Danish Center-Right partisans responded to rapidly changing party cues about the budget deficit. After an intense effort by Prime Minister Lars Løkke Rasmussen and other elites to cue the severity of the budget, co-partisans of the incumbent parties increased the extent to which they saw the budget deficit as "a problem," and to a degree that was statistically indistinguishable from the out-party. Bisgaard and Slothuus' (2018) study therefore suggests that partisans' perceived importance of current issues, including budget deficits, are indeed malleable and responsive to elites, shifting as a means of satisfying partisan instincts.

In sum, PMR on policy issues can take a variety of forms, including misperceptions about objective reality, differential attribution of credit or blame, and even changes in issue stances. On this latter point, the proposition that PMR will lead partisans to adjust opinions on various political issues finds strong empirical evidence when it comes to positional issues. But, in conceptualizing deficit spending as a valence issue, we view it to be generally unlikely that partisans would change their position on deficit spending (e.g., to regard growing deficits as a policy success for the inparty). Rather, by virtue of being a valence issue, we reason that partisans will instead change the 
importance they assign to the issue of deficits based upon which party presides over them via the presidency. We therefore test the following hypothesis:

Deficit Attention Hypothesis (H1): Partisans will assign greater importance to the issue of deficit spending when an outparty, versus inparty, president is in power.

Empirical support for this hypothesis would come with important implications for American democracy. Previous literature finds that perceived issue importance (i.e., the "passion" with which citizens regard particular issues) shapes evaluations of political candidates and vote choice (Krosnick 1990). Further, extant research suggests that public attitudes about budgetary matters are capable of influencing the legislative agenda of Congress (Jones and Baumgartner 2004) and/or that of the president (Canes-Wrone and Shotts 2004). Finally, treating deficit reduction as a more pressing priority stands to constrain the extent to which other programs can be expanded, as well as the degree to which costly (at least in the short-term) policy proposals will be given serious consideration in the mass public and/or in federal government.

\section{SURVEY EXPERIMENTS}

To test H1, we fielded a survey experiment on Amazon.com's Mechanical Turk (MTurk; e.g., Thomas and Clifford 2017) in January of $2020(n=1,024)$, followed by a far larger, preregistered experiment via Lucid (see Coppock and McClellan 2019) in February of 2020 $(n=5,034) .{ }^{8}$ While the former is a convenience sample of U.S. adults, the latter study included

\footnotetext{
${ }^{8}$ The Lucid study was pre-registered using the Open Science Framework in February of 2020 (http://osf.io). Registration materials include vignette wording, question wording, experimental protocol and treatment randomization process, statement of hypothesis, and design of the models using coding notation written in the $\mathrm{R}$ programming language. We report no differences between
} 
quotas to obtain a sample that is nationally representative in terms of age, gender, race/ethnicity, and geographic region (see Supplemental Appendix for demographic information about each sample).

The basic features of the two experiments were nearly identical. Respondents were instructed that they would be reading "a brief excerpt from a forthcoming study of government spending over the past 45 years." Respondents were also informed that this (fictitious) study excerpt had been "completed by a variety of professional economists, university researchers, and government analysts." The surveys were programmed to "block" on party identification (Gerber and Green 2012, 71-79), which was measured at the start of the survey using the canonical 7-point scale ranging from "Strong Democrat" to "Strong Republican" (see Supplemental Appendix for details). We then randomly assigned each (blocked) respondent to read one particular version of the study. While each version of the study discussed persistent deficit spending since 1973 as well as the resultant increase in national debt, the key manipulation is simply whether the study exclusively focuses on Democratic or Republican presidents. ${ }^{9}$ For partisans, the experimental manipulation is thus designed to assign responsibility for deficit spending and debt to one's

the pre-registered design plan and the results presented in this manuscript. [Link to registration page redacted for review.]

${ }^{9}$ The most direct experimental test of H1, of course, would be to manipulate the party of the sitting president. However, we viewed such a manipulation to be unlikely to succeed, especially among partisans. Emphasizing Democratic vs. Republican culpability for deficit-spending and the national debt, therefore, was deemed a superior alternative. 
TABLE 1. Experimental Vignette Wording

\begin{tabular}{|c|c|}
\hline & Vignette Text Assigned to Respondent \\
\hline $\begin{array}{c}\text { Study } \\
\text { Title } \\
\text { \& } \\
\text { Topline }\end{array}$ & $\begin{array}{l}\text { Government Spending and Deficits Under [Democratic/Republican] Presidents: 1973-2018 } \\
\text { Every [Democratic/Republican] president ran a budget deficit during their time in office, } \\
\text { our analysis found. On average, [Democratic/Republican] presidents spent around } 13.5 \% \\
\text { more each year than the federal government took in. }\end{array}$ \\
\hline $\begin{array}{c}\text { Body } \\
\text { of } \\
\text { Study } \\
\text { Excerpt }\end{array}$ & $\begin{array}{l}\text { Government spending is an issue that we often hear about in the United States. While different } \\
\text { presidents have different policy priorities, our analysis of [Democratic/Republican] presidents } \\
\text { finds several noteworthy consistencies across the } 45 \text {-year period of } 1973 \text { to } 2018 \text { (the most recent } \\
\text { year for which we were able to obtain data). } \\
\text { The majority of federal government spending is on social programs and national defense. } \\
\text { [Democratic/Republican] presidents, on average, oversaw approximately } 75 \% \text { of the federal } \\
\text { budget being spent on social programs (mainly Social Security, Medicare, and Medicaid, and to } \\
\text { a lesser extent other spending on veterans, the poor and the disabled). Approximately } 16 \% \text { of these } \\
\text { presidents' budgets were dedicated to defense-related spending. } \\
\text { However, on average, government spending during these [Democratic/Republican] presidencies } \\
\text { substantially exceeded revenue. In fact, [Democratic/Republican] presidents since } 1973 \text { spent, on } \\
\text { average, } 13.5 \% \text { more each year than the federal government took in. This means that for every } \\
\$ 100 \text { that [Democratic/Republican] presidents collected in revenue each year, they oversaw } \\
\$ 113.50 \text { being spent. } \\
\text { With [Democratic/Republican] presidents having consistently run budget deficits over many } \\
\text { years, this has resulted in a steady increase in the national debt, which is the total amount of money } \\
\text { owed by the federal government. Again, we find this pattern of increasing the national debt to be } \\
\text { remarkably consistent among [Democratic/Republican] presidents since } 1973 \text {. }\end{array}$ \\
\hline
\end{tabular}

Notes: Text within brackets represents experimentally manipulated text in the MTurk and Lucid studies.

preferred party (i.e., inparty) or one's non-preferred party (i.e., outparty). ${ }^{10}$ Table 1 features the verbatim text viewed by respondents. ${ }^{11}$

${ }^{10}$ As the vignettes were more than 800 words in total, manipulating only these two words ("Democratic" and "Republican") also helps minimize the risk of confounding (Dafoe, Zhang, and Caughey 2018).

${ }^{11}$ As we further detail below, the Lucid study also featured a "pure control" condition (i.e., $1 / 8^{\text {th }}$ of respondents were not assigned to read anything), and a "placebo control" condition (i.e., $1 / 8^{\text {th }}$ of 
It is important to emphasize that, while we manipulated the party featured in the experimental vignette, other elements of the vignette - e.g., the long-term average level of deficitspending, the average budget allocations dedicated to social programs and national defenseremained identical across conditions. ${ }^{12}$ In this way, our design minimizes the possibility of unintentional confounding whereby, for example, comparing Democratic and Republican presidents may also cue beliefs about how the two parties differ on social welfare and military spending (see Dafoe, Zhang, and Caughey 2018). ${ }^{13}$

Following the experimental vignette, respondents answered a total of six items designed to gauge perceived importance of the deficit. The wording of these various items, as well as information about the response options, are featured in Table 2. Collectively, these survey items were designed to measure the extent to which the federal deficit (and debt) is perceived as a problem in itself and, similarly, as a problem that needs to be quickly rectified by policymakers.

In both the MTurk and Lucid studies, these items had positive and statistically significant $(p<0.05)$ pairwise correlations, with Cronbach's alpha $(\alpha)$ values of 0.83 in the MTurk study and 0.80 in the Lucid study. As such, we combined these items into a single scale (Deficit Importance)

respondents read an identical article mentioning "all presidents" rather than Democratic or Republican presidents).

${ }^{12}$ To enable the (fictitious) report to be as believable as possible, we based the purported level of deficit spending (13.5\%) on the actual average according to Federal Reserve data (see Supplemental Appendix for details). Similarly, we based social welfare and health spending on reports of current levels (see Jacobson 2015).

${ }^{13}$ Nevertheless, we further explore this possibility below. 


\section{TABLE 2. Experimental Outcome Measures}

\begin{tabular}{|c|c|c|c|}
\hline & Question Text & Response Option Range & Values \\
\hline 1 & $\begin{array}{l}\text { In general, how concerned are you about the federal } \\
\text { government running budget deficits? }\end{array}$ & $\begin{array}{l}\text { "Not at all concerned" } \\
\text { to } \\
\text { "Very concerned" }\end{array}$ & 4 \\
\hline 2 & $\begin{array}{l}\text { In your opinion, how important is the issue of federal } \\
\text { budget deficits? }\end{array}$ & $\begin{array}{l}\text { "Not important" } \\
\text { to } \\
\text { "Extremely important" }\end{array}$ & 5 \\
\hline 3 & $\begin{array}{l}\text { To what extent should the federal government } \\
\text { prioritize reducing the deficit over other policies } \\
\text { (such as funding defense and social programs)? }\end{array}$ & $\begin{array}{c}\text { "Do not prioritize the deficit at all" } \\
\text { to } \\
\text { "Greatly prioritize the deficit" }\end{array}$ & 4 \\
\hline 4 & $\begin{array}{l}\text { Currently, the federal government is running another } \\
\text { large budget deficit. In your opinion, how quickly } \\
\text { does the federal government need to act in order to } \\
\text { reduce the size of the national debt? }\end{array}$ & $\begin{array}{l}\text { "Never" } \\
\text { to } \\
\text { "Immediately" }\end{array}$ & 5 \\
\hline 5 & $\begin{array}{l}\text { As you may know, spending on the military and social } \\
\text { programs (such as Social Security, Medicare, and } \\
\text { Medicaid) account for the vast majority of all federal } \\
\text { spending. To reduce the federal budget deficit, to } \\
\text { what extent should we cut spending? }\end{array}$ & $\begin{array}{l}\text { "None at all" } \\
\text { to } \\
\text { "A great deal" }\end{array}$ & 5 \\
\hline 6 & $\begin{array}{l}\text { Please tell us if you think the following policy should } \\
\text { be a top priority, important but lower priority, not too } \\
\text { important or that it should not be done: Reducing the } \\
\text { federal budget deficit }\end{array}$ & $\begin{array}{c}\text { "Should not be done" } \\
\text { to } \\
\text { "Top priority" }\end{array}$ & 4 \\
\hline
\end{tabular}

Note: The sixth item comes from the Pew Research Center, and is featured in the observational analysis below.

ranging from 0 to 1 , with higher values reflecting greater perceived importance of addressing deficit spending. ${ }^{14}$ Again, while these items differ slightly in their respective emphasis, in combination, the scale offers a reasonably holistic measure of perceived deficit importance, and with less measurement error than if only a single item had been employed (e.g., Ansolabehere, Rodden, and Snyder 2008).

${ }^{14}$ Details regarding the exact wording of all response options, as well as the distribution of scores on these scales, can be found in the Supplemental Appendix. 


\section{Experimental Results}

We first present the results of the MTurk study. ${ }^{15}$ The $y$-axes of Figure 1 indicate the average values of Deficit Importance. The left portion of Figure 1 (Panel A) specifically displays average values of Deficit Importance (with 95\% CIs) for partisans across each of the two experimental conditions. Democratic (Republican) respondents who read the "Democratic (Republican) presidents" version of the experimental treatment are featured in the "Inparty Presidents" column, while Democrats (Republicans) who read the Republican (Democratic) vignettes are included in the "Outparty Presidents" column.

As Figure 1 reveals, moving from a report about inparty presidents to a report about outparty presidents yields a substantial increase in Deficit Importance. This effect slightly exceeded 5 percentage points on the 0 to 1 scale $(p<0.001)$. Subsequent analyses confirmed that Democrats and Republicans responded in a similar fashion to the manipulation, with Democrats (Republicans) exhibiting a treatment effect equal to 5.7 (4.7), and a non-significant interaction between the manipulation and respondents' party identification $(p=0.71)$.

We further investigated the effects of partisanship by stratifying the sample across the strength of party ID. First, we examined whether "pure" Independents show any significant differences when reading about deficits under Democratic (versus Republican) presidents. Because pure Independents lack a psychological attachment to one particular party, and thus have little reason to engage in PMR (e.g., Lavine, Johnston, and Steenbergen 2012), the importance that they place on addressing the deficit should be relatively unaffected by the party that happens to be blamed for overspending. Indeed, as the right portion of Figure 1 (Panel A) indicates, Independents

\footnotetext{
${ }^{15}$ Underlying regression model output can be found in the Supplemental Appendix.
} 


\section{FIGURE 1. Partisanship \& Importance of Government Overspending (MTurk)}

\section{$\underline{\text { Panel A }}$}
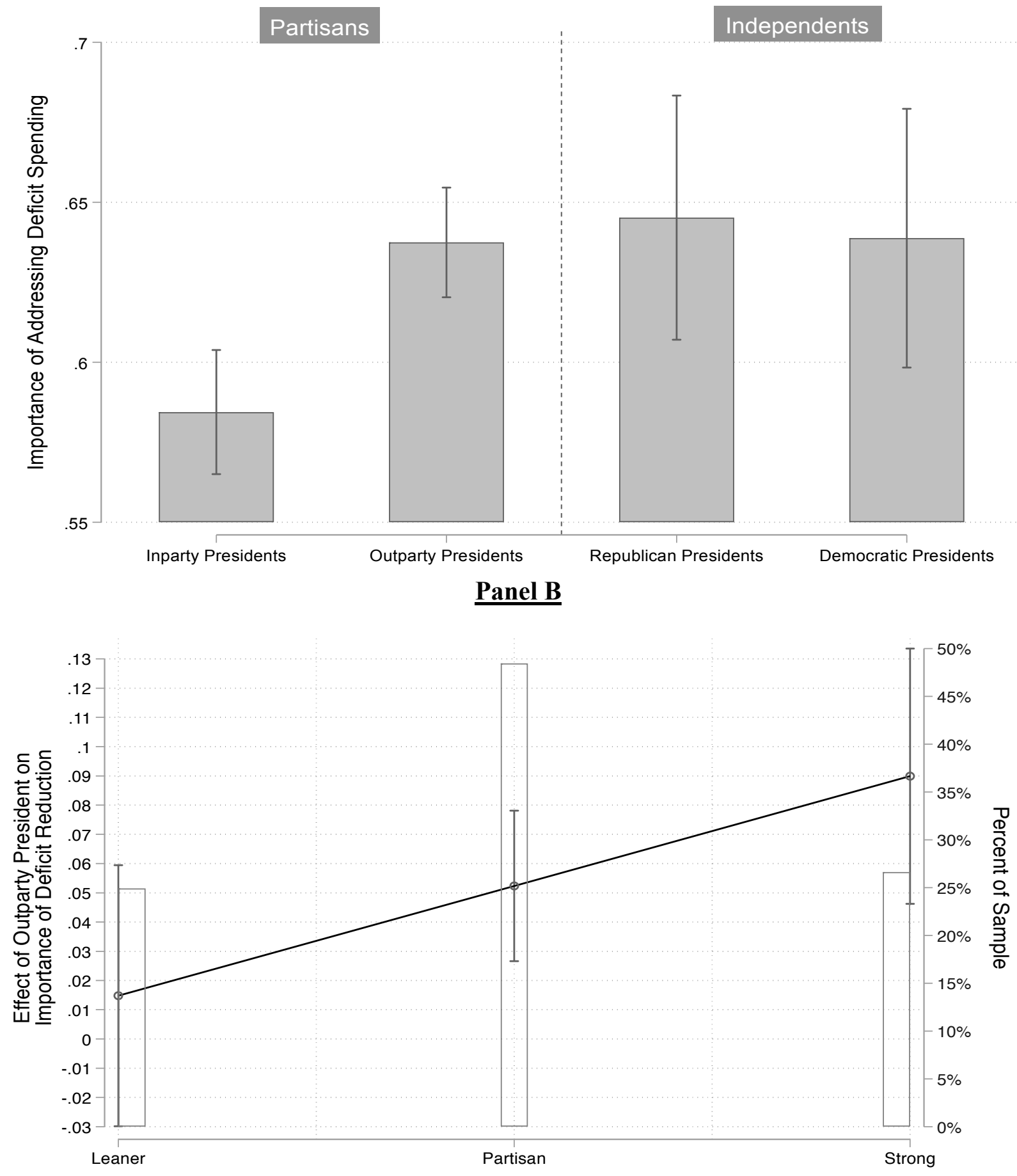

Notes: Dependent variable is a six-item additive scale, with higher values indicating greater perceived importance of addressing budget deficits. Panel B's $y$-axis shows treatment effect of "Outparty presidents" treatment relative to "Inparty presidents" treatment; right $y$-axis displays share of each partisan group in the sample. 95\% CIs shown. MTurk data (total $\mathrm{N}=1,024$ ). 
exhibited virtually identical scores on the Deficit Importance scale regardless of which party they read about $(p=0.82)$.

Next, if partisan bias is indeed the key mechanism underlying these results, it stands to reason that partisans with stronger attachment to their party will be more inclined to engage in motivated reasoning, and thus exhibit stronger treatment effects. As shown in Panel B of Figure 1, we indeed find a positive, significant interaction between the treatment and party identification strength $(p<0.05)$, with the strongest partisans exhibiting a predicted treatment effect of 9 percentage points on the Deficit Importance scale. ${ }^{16}$ The MTurk study results thus provide strong initial support for the Deficit Attention Hypothesis (H1).

Turning now to the 2020 pre-registered Lucid study, the pattern of results is very similar to that of the previous experiment. As Figure 2 (Panel A) shows, partisans again assigned greater importance to addressing deficit spending when reading about outparty (versus inparty) presidents. This effect was approximately 7 percentage points (an $11 \%$ increase; $p<0.001$ ). Subsequent analyses again found that Democrats and Republicans exhibited markedly similar effects (.06 and .07 , respectively, with a non-significant interaction between the experimental manipulation and party identification; $p=0.36$ ). We again find that, as shown in Figure 2 (Panel A), Independents did not exhibit any significant difference in Deficit Importance across conditions $(p=0.56)$. Lastly, Panel B of Figure 2 demonstrates that, consistent with the MTurk results above, treatment effects increased with partisan strength $(p<0.05)$, with the strongest partisans exhibiting a predicted treatment effect of nearly 9 percentage points on the Deficit Importance scale.

\footnotetext{
${ }^{16}$ The right $y$-axis of this graph indicates the share of respondents falling into each of the three categories of partisan strength.
} 


\section{FIGURE 2. Partisanship \& Importance of Government Overspending (Lucid)}

\section{$\underline{\text { Panel A }}$}
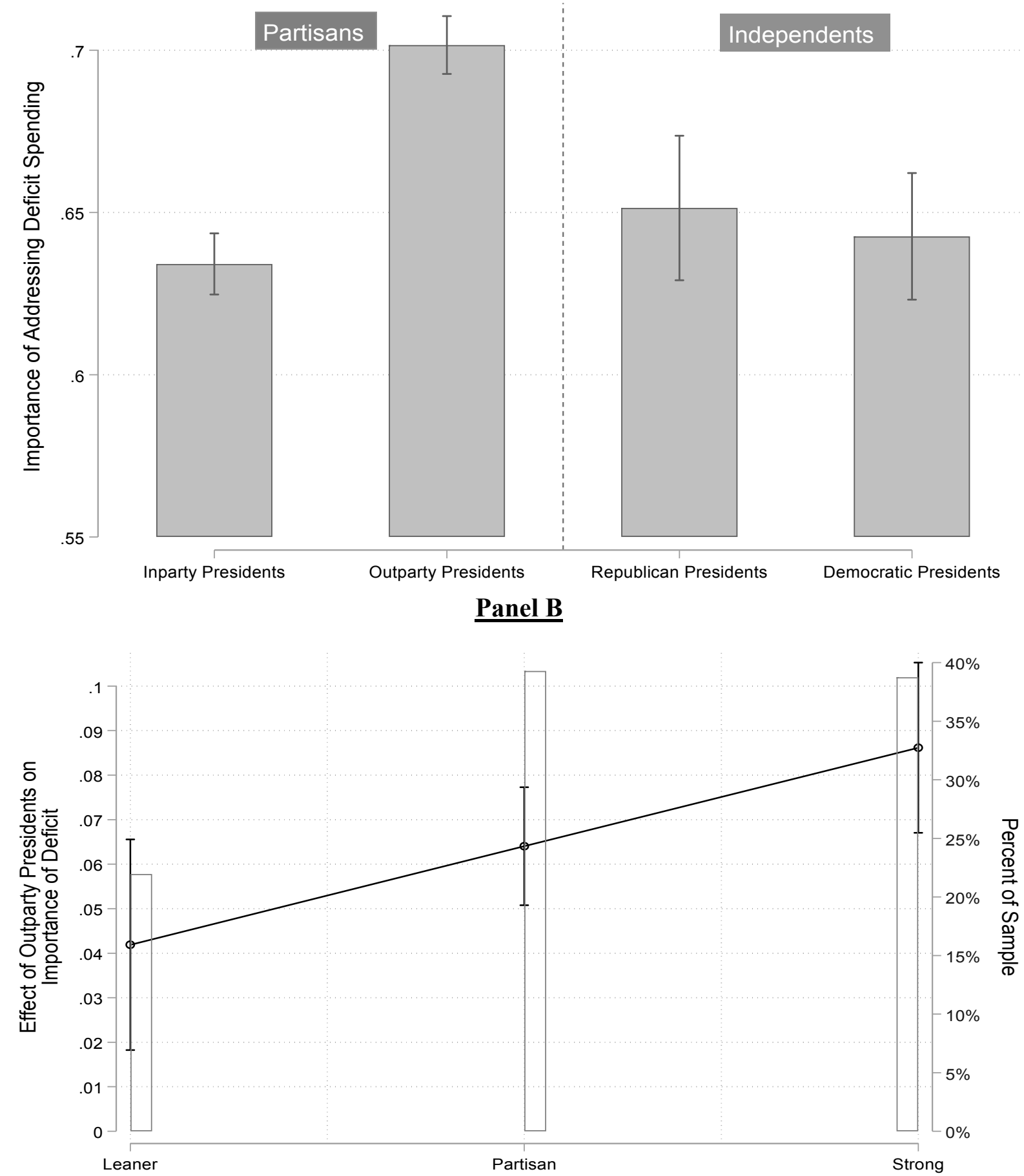

Notes: Dependent variable is a six-item additive scale, with higher values indicating greater perceived importance of addressing budget deficits. Panel B's $y$-axis shows treatment effect of "Outparty presidents" treatment relative to "Inparty presidents" treatment; right $y$-axis displays share of each partisan group in the sample. 95\% CIs shown. Lucid data (total $\mathrm{N}=5,034$ ). 


\section{Manipulation Checks \& Investigating Mechanisms}

The main results of the MTurk and Lucid experiments provide strong and consistent support for H1. In this section, we discuss the results of a series of additional tests designed to further investigate the robustness of these findings.

First we summarize the results of factual and subjective manipulation checks (see Kane and Barabas 2019) in both the MTurk and Lucid experiments, all of which appeared immediately after the outcome measures. To ensure that the key manipulation (i.e., the party of the presidents) was perceived, we asked respondents to identify the party that was discussed in the article. We also asked respondents to identify whether, according to the article, [Democratic/Republican] presidents reportedly: ran budget deficits, ran budget surpluses, oversaw balanced budgets, or ran more budget surpluses than deficits. Next, we asked, "According to the article, about how much more (on average) did [Democratic/Republican] presidents spend compared to the amount the federal government took in?", with responses ranging from " $0.1 \%$ " to " $90 \%$ ". We detail the results of these analyses in the Supplemental Appendix, but, in brief: large majorities answered these questions correctly (regardless of party identification), and, in the case of the first manipulation check, responses significantly covaried with treatment assignment as intended.

The Lucid study also featured a subjective manipulation check, which asked respondents for their level of agreement with the following statement: "In recent decades, [Democratic / Republican] presidents have run budget deficits and increased the national debt." Responses ranged from "Strongly Disagree" (1) to "Strongly Agree" (7). We find that our manipulation strongly and significantly affected agreement (by approximately 1 point on the scale), and that this was true for both Democratic and Republican respondents. Specifically, the Democratic (versus Republican) manipulation predicts a significant increase in agreement that Democratic presidents 
have run budget deficits and increased the debt, and the same for the Republican (versus Democratic) manipulation vis-à-vis perceptions of Republican presidents (see Supplemental Appendix for details).

Collectively these manipulation check results indicate that the key manipulation, as well as the deficit-related content of the vignettes, were largely perceived by respondents, and that, as intended, the experimental manipulation did indeed affect beliefs about Republican/Democratic presidents' culpability for government overspending.

Finally, as noted above, the Lucid study featured two additional control conditions that the MTurk sample did not include. These conditions comprise $25 \%$ of the total sample $(n=1,269)$. One condition was a "pure control," in which respondents were not assigned to view any vignette, instead proceeding directly to the outcome measures. The other condition served as a "placebo control," in which respondents read the same vignette that appears in Table 1 with one substitution: partisan language (“[Democratic/Republican] presidents”) was replaced with non-partisan language ("all presidents").

These additional conditions help us better understand the nature and composition of the partisan effects we observe above. Specifically, while the results in Figures 1 and 2 indicate that the party of the president matters for partisans' concern about deficit spending, it is unclear if this effect is due to respondents (1) lowering Deficit Importance when an inparty president is responsible (i.e., a defensive form of PMR), (2) increasing Deficit Importance when an outparty president is responsible (i.e., an offensive form of PMR), or (3) some combination of these two mechanisms.

Figure 3 plots OLS regression coefficients (with 95\% CIs) for the placebo and two main experimental conditions relative to the pure control condition (which functions as the baseline 


\section{FIGURE 3. Treatment Effects Involve Both Offensive and Defensive Mechanisms (Lucid)}

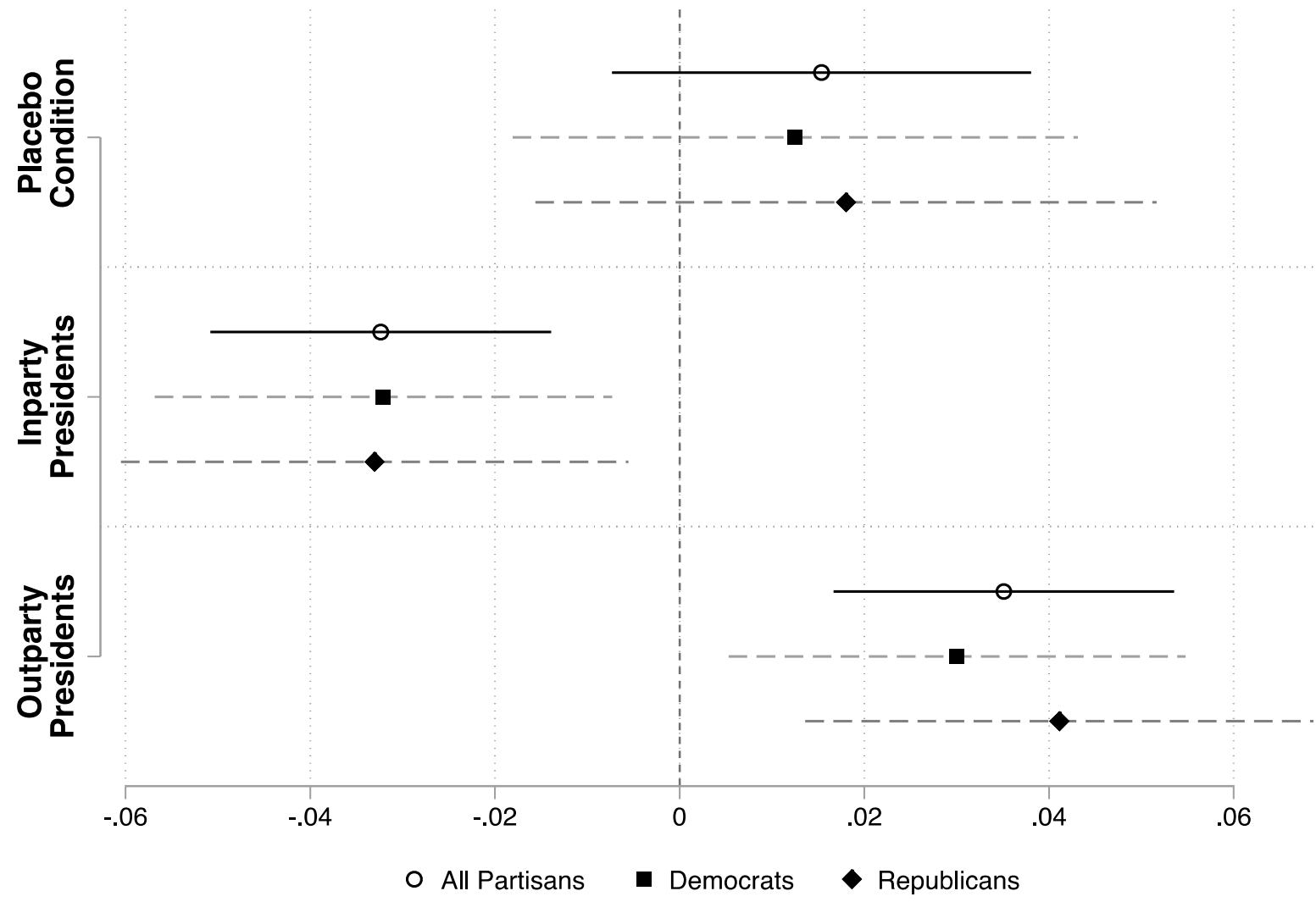

Notes: Dependent variable is a six-item additive scale, with higher values indicating greater perceived importance of addressing budget deficits. The $x$-axis displays the treatment effect of a given experimental condition. Excluded experimental condition is a pure control condition (i.e., respondents were not given any information). "Placebo condition" discussed "all presidents" rather than presidents of one party. 95\% CIs shown. Lucid data (total $\mathrm{N}=5,034)$.

condition), with Deficit Importance specified as the dependent variable. Coefficients appear for all partisans, as well as for Democrats and Republicans separately. The figure illustrates, first, that Democratic and Republican respondents exhibited markedly similar treatment effects. Second, likely owing to its explicit discussion of deficit spending, the placebo condition had a slightly positive effect on Deficit Importance, though this effect was not statistically significant $(\mathrm{p}=.18)$. Third, relative to the pure control, the "inparty presidents" and "outparty presidents" treatments have roughly symmetric effects: the former lowered Deficit Importance by 3.2 percentage points 
$(\mathrm{p}<.001)$, while the latter increased Deficit Importance by 3.5 percentage points $(\mathrm{p}<.001)$. However, relative to the placebo control, the main effect observed above appears to be largely driven by defensive, rather than offensive, considerations: the former effect is (negative) 4.8 percentage points $(\mathrm{p}<.001)$, while the latter is only 2.0 percentage points $(\mathrm{p}<.05)$.

These patterns suggest that, depending upon the political context, partisans are inclined to either decrease $o r$ increase the importance they assign to addressing deficit spending. Specifically, partisans augment the importance of the deficit when the available evidence shows outparty culpability, potentially representing a form of "political ammunition" that can be wielded to criticize an outparty president. However, we observe a noticeably stronger tendency to defensively downplay the importance of the deficit when one's own party appears culpable for deficit increases. In both cases, then, partisan-motivated reasoning appears to be guiding citizens' perceived importance of the deficit, even in the absence of explicit elite cues to do so, and with Democrats and Republicans being nearly equally susceptible to such partisan instincts.

\section{OBSERVATIONAL DATA}

The previous section found consistent experimental evidence for (H1), both among Democrats as well as Republicans. Yet to what extent do we observe such effects in the real world? To investigate this question, we draw upon two separate data sets, both of which leverage the federal transfer of power from the (Democratic) Obama Administration to the (Republican) Trump Administration in January of 2017. 
The first data set includes two separate Pew Research Center (PRC) samples, one interviewed in January of 2016 and the other interviewed in January of $2018 .{ }^{17}$ These were randomly selected, nationally representative samples of adults residing in the United States (total $n$ used in the analysis $=1,545)$. We selected these two surveys based upon (1) their proximity to the change in presidential administrations, and (2) the inclusion of the same measure of concern regarding deficit spending. Specifically, respondents were asked to indicate the degree to which, for the current president and Congress, "Reducing the budget deficit" should be a "Top priority", "Important but lower priority", "Not too important", or "Should not be done". Because over 50\% of the sample selected "Top priority", we dichotomized this variable such that 1= "Top priority", and $0=$ any other response, to simplify the analyses below. ${ }^{18}$ This binary outcome measure serves as our dependent variable of interest for the PRC analyses.

The second data set comes from the Democracy Fund's "Voter Study Group" (VSG) 2019 panel data set. The VSG includes nearly 8,000 respondents, repeatedly interviewed (online) in late 2016 (during the Obama presidency), July of 2017 (early in the Trump presidency), and again in January of 2019 (later the Trump presidency), yielding a total $n$ size of nearly 20,000 for our analysis. ${ }^{19}$ In each of these waves, respondents were asked to rate the importance of various issues,

${ }^{17}$ Details concerning the sampling and interview methodology can be found in the Supplemental Appendix.

${ }^{18}$ As discussed below, we specify logistic regression models; however, the pattern of results remains the same when treating the scale as ordinal and specifying an ordered logistic model (see Supplemental Appendix).

19 More information regarding the 2019 VSG data can be found here: https://www.voterstudygroup.org/publication/2019-voter-survey-full-data-set 
including "the budget deficit." Respondents could rate the budget deficit as "Very important", "Somewhat important", "Not very important", "Unimportant", or, in rare cases (less than $2 \%$ in any given wave) voluntary decline to answer. Similar to the PRC data, over $50 \%$ of the sample indicated that the budget deficit is a "very important" issue. Thus, we again created a dichotomous variable for which $1=$ "Very important" and $0=$ any other response. This serves as our dependent variable for the VSG analyses.

\section{Results}

If partisans engage in motivated reasoning on the issue of government deficits, as per $\mathbf{H 1}$, the change in presidential administrations should spur changes in partisans' perceived importance of addressing the deficit. Specifically, according to H1, the change from the Obama Administration to Trump Administration should result in greater perceived importance of the deficit among Democrats, yet lower perceived importance of the deficit among Republicans.

To test this expectation using the PRC data, we specified a logistic regression model featuring an interaction between a trichotomous categorical measure of party identification (Democrat, Independent, or Republican) and the year of the survey $(0=2016,1=2018)$. To account for any potential imbalances between the two samples, we also included controls for respondents' age, family income, education level, gender identification, racial identification, and ideological self-placement. ${ }^{20}$

${ }^{20}$ Details regarding question/response wording, as well as descriptive statistics, for these variables (in both the PRC and VSG analyses) can be found in the Supplemental Appendix along with regression model output. 
The results of this analysis are featured in the top panel of Figure 4. The $y$-axis displays the marginal effect of changing from the Obama Administration (i.e., the 2016 survey) to the Trump Administration (i.e., the 2018 survey) on the probability of identifying "reducing the deficit" as a top public policy priority. For Democrats, Figure 4 shows this estimated effect to be nearly zero ( $p=0.94)$, indicating essentially no change in perceived importance of deficits compared to 2016 . The same is true of Independents, who exhibited a small, non-significant negative effect $(p=0.81)$.

In contrast, moving from the Obama Administration to the Trump Administration, Republicans exhibit a more than 12 percentage-point reduction in the probability of identifying deficit reduction as a top priority $(p<0.01)$. Remarkably, we observe this effect despite only two years having elapsed since the first survey and, perhaps even more importantly, the fact that the budget deficit had actually increased each fiscal year, resulting in an even larger national debt in 2018 than in $2016 .{ }^{21}$ Thus, Figure 4 provides additional evidence for H1, though, in contrast to the experimental evidence, exclusively among Republicans.

We employ a similar methodological approach in examining the VSG panel data. Specifically, we specified a logistic regression model featuring an interaction between a trichotomous categorical measure of party identification (measured in the 2016 (baseline) wave) and a categorical measure of the three survey waves (2016, 2017, and 2019), with standard errors clustered by respondent.

Panel B of Figure 4 displays the results of this analysis. Like Panel A, the $y$-axis in Panel $\mathrm{B}$ indicates the marginal effect of changing from the Obama to Trump administrations on the

\footnotetext{
${ }^{21}$ See Federal Reserve data located here: https://fred.stlouisfed.org/series/FYFSD
} 
FIGURE 4. Change in Presidential Administrations and Importance of Addressing Deficit

\section{Panel A (Pew Research Center Data)}

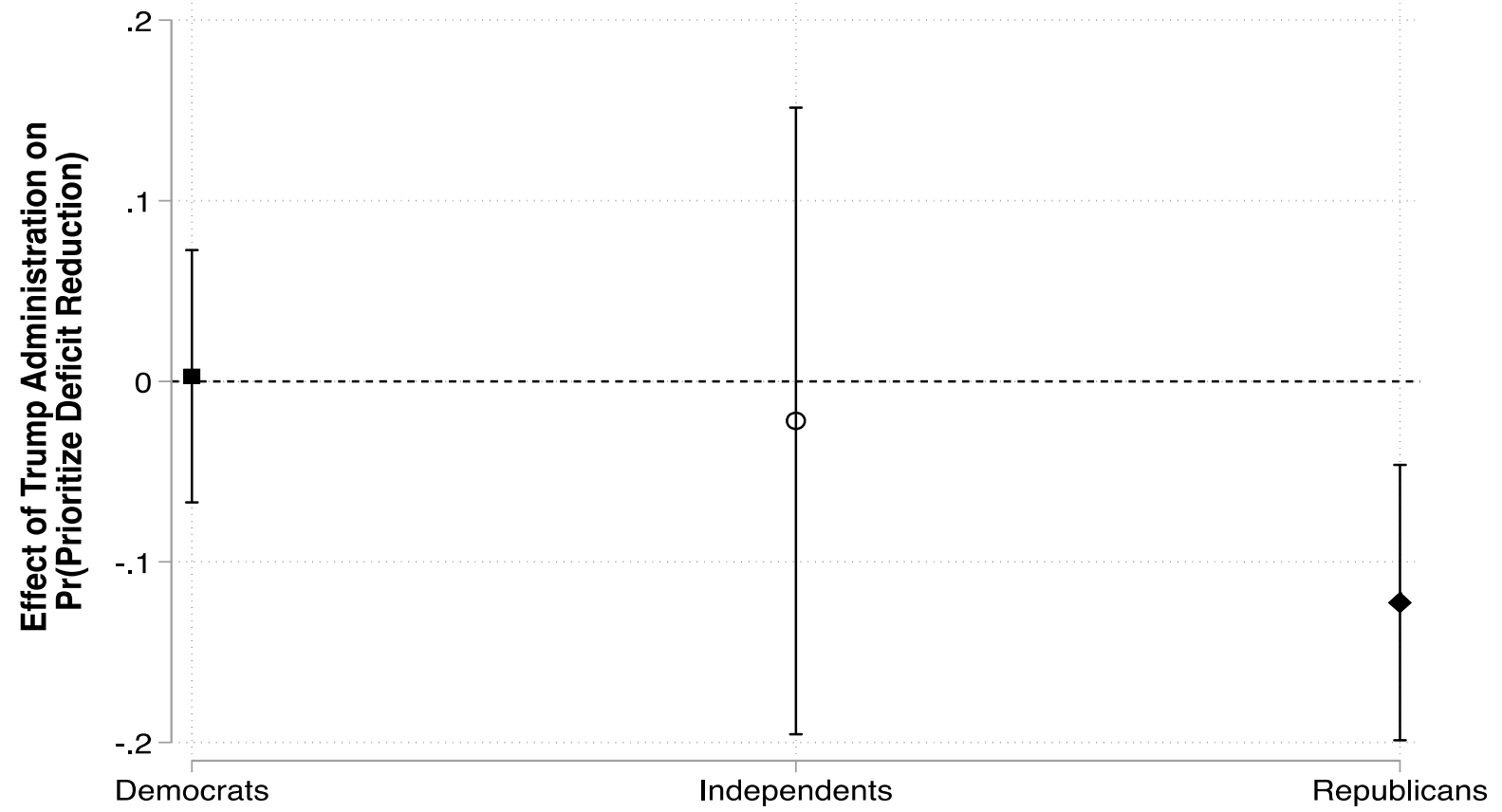

\section{Panel B (Voter Study Group Data)}

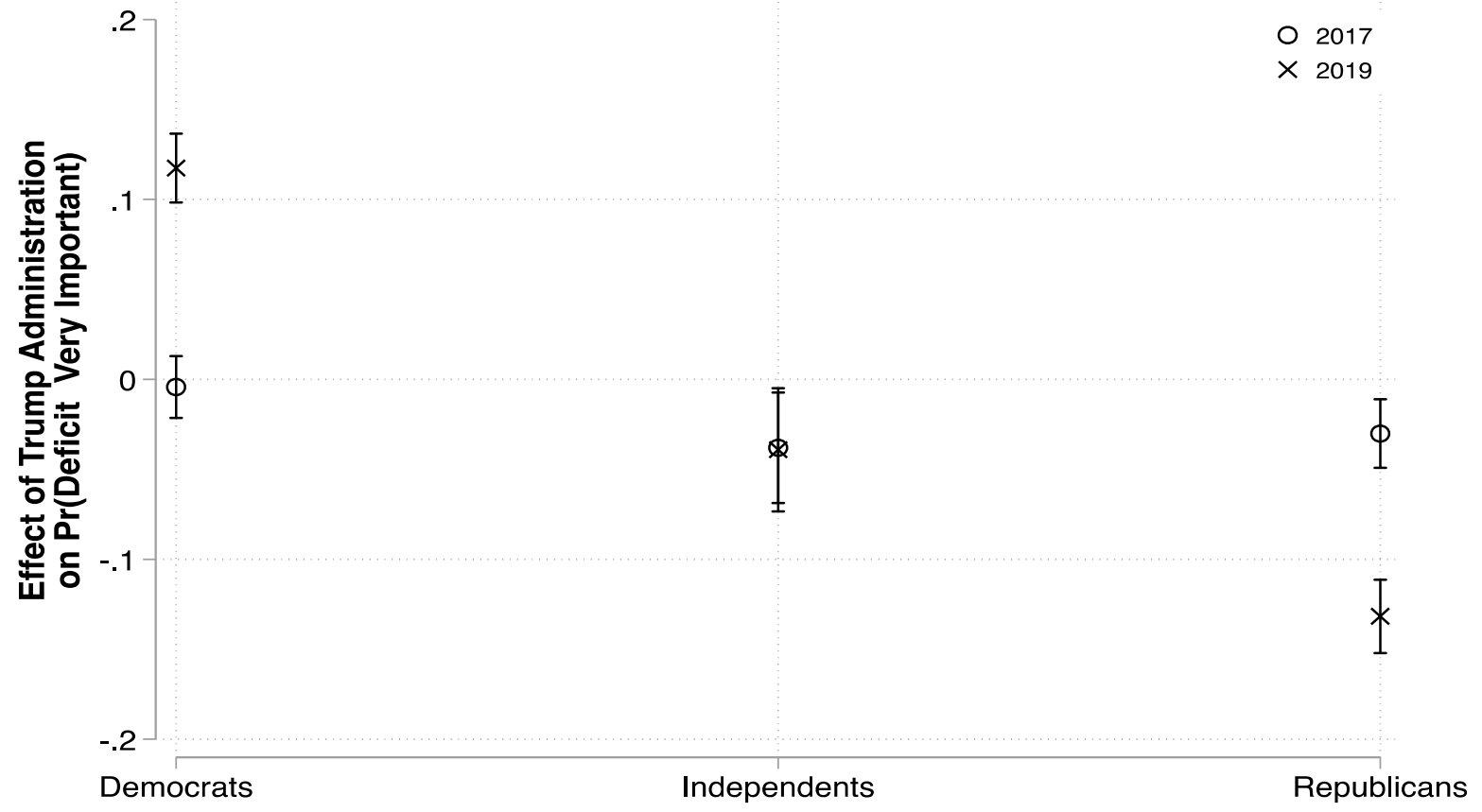

Notes: Dependent variable coded 1="'reducing the budget deficit... is a top priority" (PRC) / "addressing budget deficit is...very important" (VSG), and coded 0 otherwise. PRC data from 2016 and 2018; VSG data are panel data collected in 2016 (baseline year), 2017 and 2019. The $y$-axis of both figures displays effect of changing from Obama Administration (2016) to Trump Administration on the dependent variable, while the $x$-axis displays these estimates for each partisan group. $\mathrm{N}=1,545$ (PRC) and 19,559 (VSG). 
probability of identifying the budget deficit as a "Very important" issue. Beginning first with the effect of moving from the baseline year (2016) to 2017 (indicated by the hollow circles), we see that Democrats again showed a near-zero change in perceived importance of the deficit $(p=0.63)$. Republicans, on the other hand, do show a significant decrease in perceived importance, on the order of 3 percentage points $(p<0.001)$. However, if we treat Independents essentially as a baseline (given that they have less reason to engage in partisan-motivated reasoning), it implies that the negative effect observed among Republicans in 2017 was not due to PMR but, perhaps, to other non-partisan considerations that were also on the minds of political Independents.

Far more dramatic, however, are the results for 2019 (indicated by the " $\mathrm{x}$ " symbols in Figure 4). While we observe essentially the same result among Independents, we see a marked increase in perceived deficit importance among Democrats: compared to 2016, the probability that Democrats viewed the deficit as "Very important" increased by nearly 12 percentage points $(p<0.001)$. In contrast, over the same span of time, Republicans exhibited a more than 13 percentage-point decrease in perceived deficit importance $(p<0.001)$. This pattern is precisely in line with H1, and strongly suggests partisan-motivated reasoning about the importance of addressing the federal deficit among both Democrats and Republicans.

Thus, across the PRC and VSG data sets, we find strong evidence in support of $\mathbf{H 1}$, and with effect sizes that were noticeably larger than those observed in the experimental analyses. Partisan-motivated reasoning was primarily apparent among Republicans in the PRC data, but effects were symmetrical across the parties (and of comparable size to the PRC result among Republicans) in the VSG data. It is important to emphasize, again, that, over the time frame we analyzed, both deficits and the total amount of government debt increased. This renders the existence of PMR all the more notable - perhaps especially in the case of Republicans, who clearly 
decreased perceived importance - insofar as it requires, at least to some extent, disregard for changes in objective reality. These findings therefore also accord with those of Crosby and Holbrook (2019), who find that public support for a balanced budget amendment is not significantly related to the actual size of deficits or levels of debt.

Overall, then, the experimental and observational results are quite complementary. Our experimental results showed evidence that even with information from an (ostensibly) objective source about the magnitude of deficit spending (as opposed to explicitly partisan elite cues), partisans in the mass public engage in motivated reasoning about the importance of deficit spending. Remarkably, we observe larger effects in the observational analyses, potentially because elite partisan cues are also present.

Thus, the observational data analyses raise the question of whether partisan news media-long known to directly and indirectly shape partisan attitudes and beliefs (e.g., Levendusky 2013) may, itself, elevate (or obscure) deficit spending as an important issue. If partisan media are engaging in such agenda-setting (e.g., Boydstun 2013), it could help account for some of the sizable shifts in attention to deficit spending that we observe among partisans in the mass public. Evidence of such efforts would also indicate that, along with citizens, elites operating in partisan media similarly approach the issue of overspending with partisan ends in mind. To explore these questions further, in our final section we turn to a large-scale text analysis of televised partisan news media.

\section{ANALYSES OF PARTISAN MEDIA}

The preceding sections found that both Republican and Democratic identifiers engage in PMR on the issue of federal budget deficits and debt. In the present section we next evaluate H1 in the context of partisan media. Applied to this realm, $\mathbf{H 1}$ predicts that media mentions of the 
deficit should increase or decrease depending upon the party of the incumbent president. Specifically, mentions will be more frequent on Republican-oriented (Democratic-oriented) programs when a Democratic (Republican) president takes office. As with partisan citizens, this expectation is consistent with the notion that partisan media adjust their attention to deficits in order to satisfy partisan instincts (e.g., protect the inparty and attack the outparty).

To evaluate these expectations, we performed both automated and manual content analyses of the FOX News Network's Hannity television show and MSNBC's The Rachel Maddow Show. These programs were chosen due to their relatively long runs on two of the most prominent partisan media sources in U.S. media (e.g., Coe et al. 2008). We obtained transcripts of both shows from the Nexis Uni database, downloading all available full-text records from the platform for the period spanning the entire Obama administration and the Trump administration up to April 21, 2020 (when initial analysis was performed). We obtained all available transcripts on Nexis Uni, resulting in a set of 4,499 unique transcripts from the two shows. To further process this corpus, which included over 19 million words, transcript text was tagged by speaker using a custom parser. ${ }^{22}$ Having determined the speaker of each sentence, we then filtered the corpus to include only words spoken by hosts Sean Hannity or Rachel Maddow, respectively (as we are primarily interested in these hosts' framing efforts rather than the potentially more diverse frames of the shows' guests). We next used a simple lexicon of terms designed to comprehensively identify mentions of the

\footnotetext{
${ }^{22}$ For each passage we were able to identify the speaker using regular expressions that searched for fully capitalized words followed by colons. Because the transcripts use this convention when a new speaker speaks, all transcript text (exclusive of metadata) is bounded by either the host's name or another speaker's name.
} 
national debt or the federal budget deficit. The Supplemental Appendix describes this lexicon and the filters we used to reduce false positives, and includes a confusion matrix demonstrating the validity of the approach. Our strategy relied upon simple tools: we used string matches to identify mentions of the words "deficit(s)" and "debt", and then eliminated as many false positives as possible by parsing the linguistic context of each mention. This automated keyword strategy provides us with a basic sense of how often we observe "debt" and "deficit" mentions in partisan news over time.

To capture greater nuance contained in the transcripts, we also included a manual content analysis. Two coders (one of this study's authors and one graduate student) independently handcoded 200 randomly selected transcripts (50 from each of the four show-president combinations). Each coder assessed whether mentions of the debt or the deficit explicitly attributed blame to the incumbent president based upon the context of the mention. Together, these two analyses enable us to investigate the extent to which partisan media systematically vary attention to government overspending based upon which party controls the presidency.

\section{Results}

First, we consider the automated content analytical results. A comparison of transcripts from Hannity and The Rachel Maddow Show across the Trump and Obama administrations shows that Hannity's mentions of the debt are more strongly related to presidential incumbency than the mentions made on The Rachel Maddow Show. Figure 5 captures this variation by plotting the number of debt and deficit mentions per week on each program, as measured by our automated protocol. 
FIGURE 5. Mentions of Debt and Deficit per Week, Hannity vs. The Rachel Maddow Show, 2008-2020

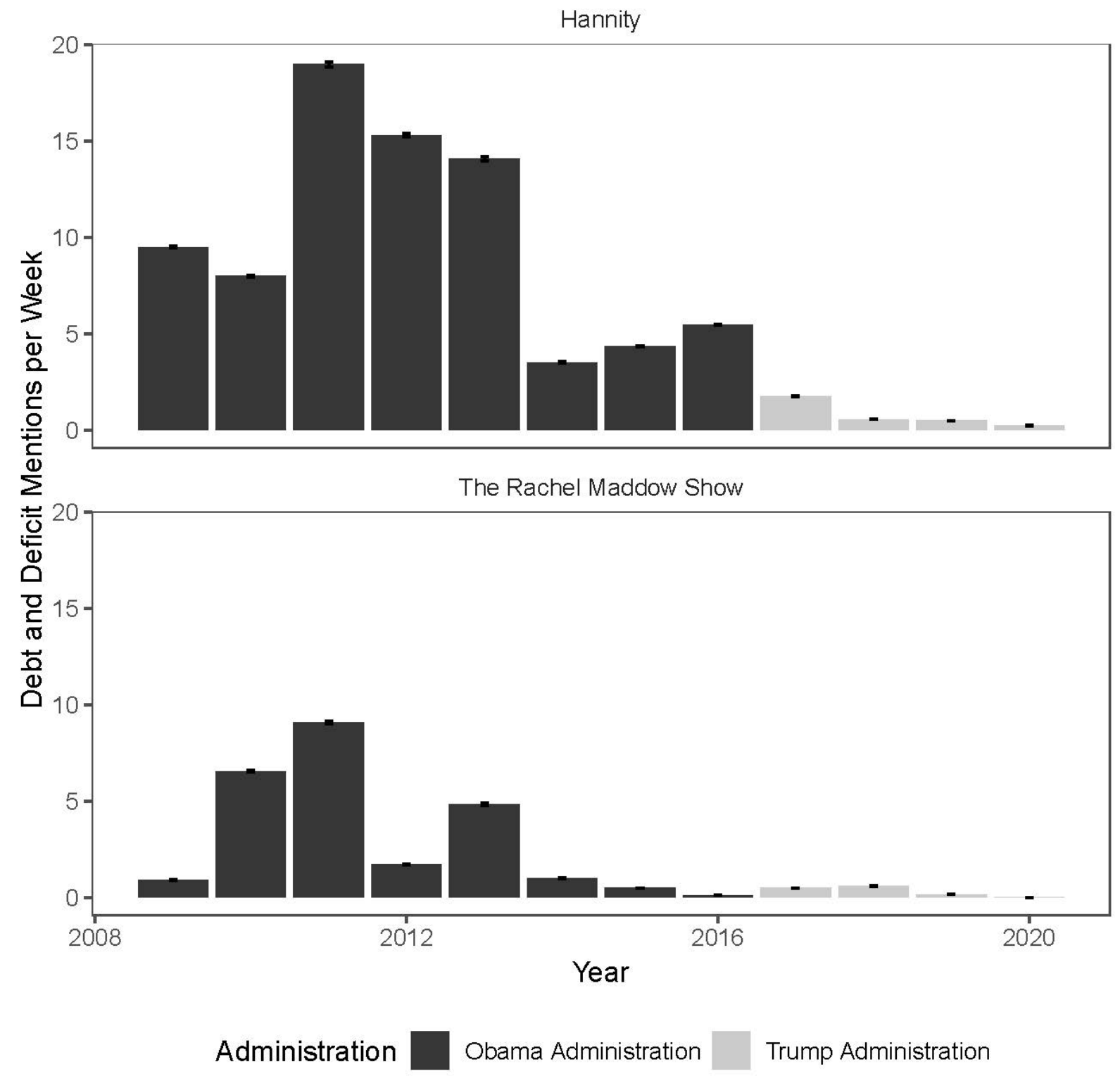

Notes: The Hannity dataset included 2,280 unique transcripts (around 3.9 per week) and the Rachel Maddow dataset included 2,212 unique transcripts across 586 (around 3.8 per week). Content is aggregated by week. Each transcript is filtered to include only transcript text spoken by the respective hosts of the programs. 95\% CIs shown.

Specifically, Figure 5 reports weekly mentions in each year from 2009 to 2020 . The counts are weighted by transcript length to ensure a fair comparison (Hannity transcripts were somewhat 
longer than Maddow transcripts on average). This initial view of the data reveals clear and statistically significant differences across the shows and eras (significance tests were performed using $t$-test comparisons of weekly average mentions of debt and deficit issues). Beginning with the top panel of Figure 5, Hannity mentions the debt and deficits substantially more during the Obama administration than during the Trump administration, as mentions peaked in 2011 at 11.9 per week and remained high throughout the remainder of the Obama years. 2011 is a salient year for debt and deficit discourse, given the debt-ceiling crisis that was eventually resolved by the Budget Control Act in August of that year. In the wake of those events (and the similar circumstances of 2013), mentions remained relatively high on Hannity. It is also quite likely that election year coverage recalled these earlier disputes, as 2016 witnessed another significant increase in debt and deficit mentions on Hannity relative to $2015(p<0.01)$.

But after Donald Trump assumed office in 2017, Hannity's mentions of the debt and deficit declined from around 2.98 per week to about 1.01 per week $(p<0.01)$. In the years following Trump's inauguration, mentions would remain below this mark, as 2018, 2019, and 2020 (an election year for the Republican incumbent) all witnessed fewer than one mention per week of the debt or deficits on Hannity. This sudden and dramatic decline in attention to government overspending is fully consistent with $\mathbf{H 1}$ and, again, is especially notable given that the federal government continued to run sizable deficits, and thus further increased the total amount of public debt, between 2016 and 2019.

On The Rachel Maddow Show (see bottom panel of Figure 5), mentions of the debt and the deficit also declined from the late 2000s to the late 2010s. But while mentions peaked at around 7.4 per week in 2011 due to the budget crisis (much akin to coverage on Hannity), the change in presidential administration did not, in contrast to Hannity, lead to a dramatic change in attention 
to overspending. Yet while we do not find strong evidence for $\mathbf{H 1}$ here, Maddow's coverage did include fewer debt and deficit mentions in 2012, an election year, than in 2011 (a decrease of around 6 mentions per week), and witnessed a similar decrease from 2015 to the critical 2016 election (a decrease of around 0.4 mentions per week; $\mathrm{p}<0.01$ ). While election years featured a great deal of debt and deficit discussion on Hannity, The Rachel Maddow Show witnessed declining coverage relative to years like 2011 and 2013 (when budget considerations were more newsworthy). Though only speculative, this pattern could also have emerged from strategic electoral purposes: fewer mentions of deficits might be advantageous to the incumbent party, for which large budget deficits are likely to be viewed negatively.

Comparing the two hosts' coverage style, we find that Hannity's coverage of the debt and deficit exceeded Maddow's coverage by around 6.8 mentions per week during the Obama Administration $(p=0.001)$. The same cannot be said of the Trump administration, a period during which Hannity aired a small and non-significant surplus of debt and deficit coverage relative to Maddow $(\delta=0.5$ mentions per week; $p=0.001)$. Together, the results offer suggestive evidence that Hannity's discussion of the debt and deficits was driven by partisan considerations, while Maddow's mentions were more responsive to the prevailing topics of the day (such as the aforementioned debt-ceiling crises in 2011 and 2013). In order to examine these results more fully, we next turn to a manual content analysis of these transcripts.

\section{Hand-Coded Analysis of Debt and Deficit Mentions}

The above results suggest that partisan media attention to deficits vary for politically motivated reasons. However, two distinct-and perhaps even counter-balancing-genres of persuasive messaging may simultaneously exist in these data. Specifically, our primary interest is 
in mentions of the deficit/debt as it regards the current presidential administration. It is possible, though, that some of the mentions arise from referencing previous presidential administrations' actions, or from attributing blame to Congress or other actors rather than the sitting president.

To better understand the context in which debt and deficit issues were mentioned on Hannity and Maddow, we employed a manual content analysis of responsibility attributions associated with the mentions in our dataset. We selected a random sample of 200 transcripts (100 Maddow and 100 Hannity transcripts evenly divided across the Obama and Trump administrations), and employed a simple binary coding strategy that identified whether debt or the deficit was mentioned $(1=$ Yes, $0=$ No), and whether responsibility attributions targeted either the incumbent (1) or any other source, including past presidents (0). This coding strategy allows us to identify the proportion of transcripts for which there was at least one clear mention of the deficit that blamed the sitting president, across presidential administration and transcript sources. Our coders' interrater reliability scores were strong: we report a Cohen's Kappa of 0.91 for the existence of a debt/deficit mention $(p<0.01)$ and a Cohen's Kappa of $0.82(p<0.01)$ for the responsibility attribution measure.

The results of this analysis are presented in Figure 6. The height of the bars in this figure represent the overall percentage of transcripts with debt or deficit mentions from each transcript and period. As this figure reveals, we find clear evidence that Hannity made many explicit attributions of responsibility to Obama during his time in office. However, the same was not true of Hannity during the Trump administration, wherein mentions became dramatically less frequent: explicit responsibility attributions declined from $38 \%$ of coded transcripts to a mere $2 \%$ of coded 
FIGURE 6. Percent of Hand-Coded Transcripts Containing At Least One Explicit Debt/Deficit Attribution to Incumbent President, Hannity vs. The Rachel Maddow Show

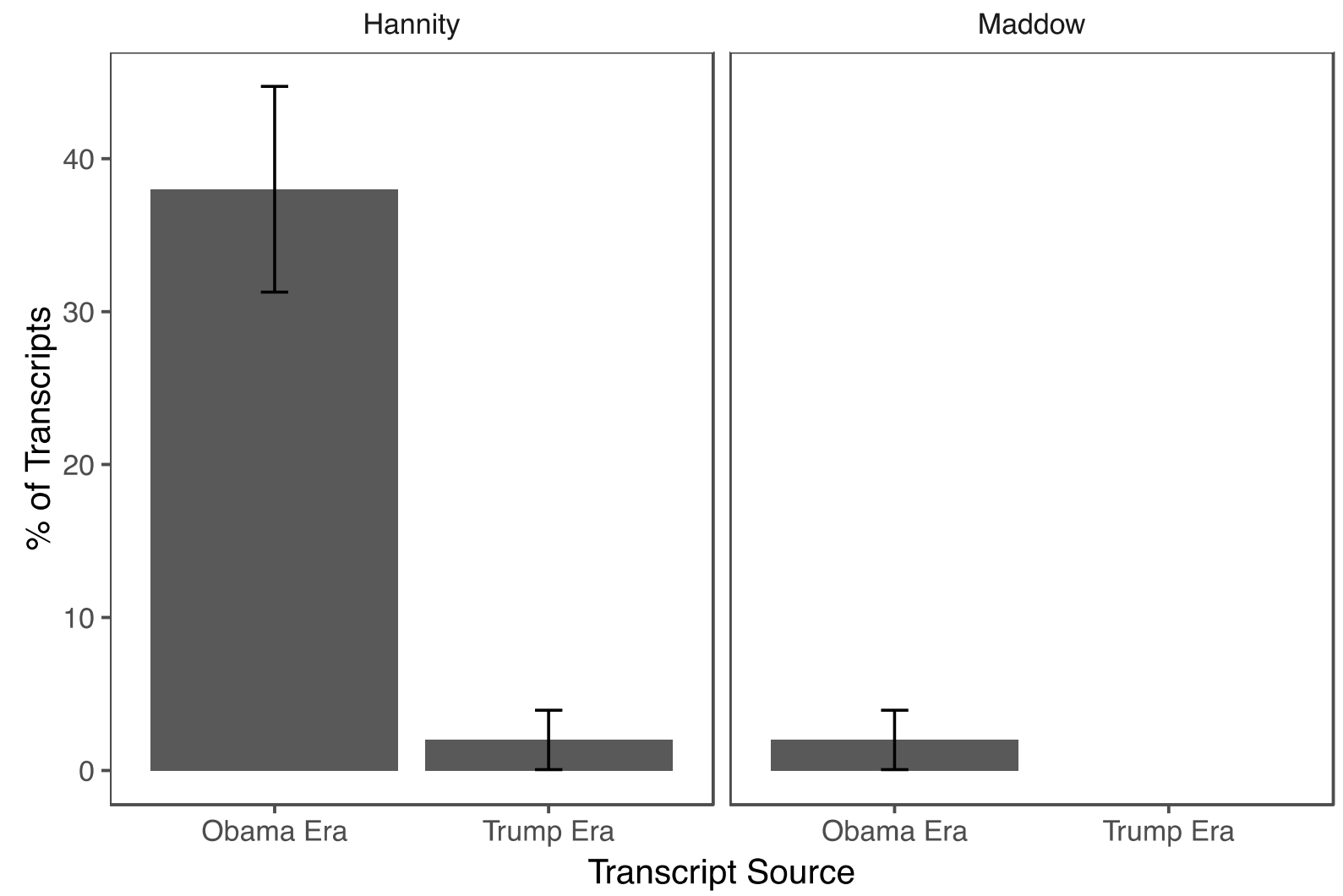

Notes: Overall $\mathrm{N}=200$; Each of the four columns in Figure 6 represent findings from 50 randomly selected transcripts from each administration/network pairing. As texts were randomly selected, they are distributed across the two time periods reflected in the columns of each facet relatively uniformly. $95 \%$ CIs shown (calculated based upon binomial distribution to prevent overlap with 0 ).

transcripts after the change in administration $(\mathrm{p}<0.01) .{ }^{23}$ Again, this pattern is fully consistent with H1.

In contrast, Maddow explicitly blames the incumbent $2 \%$ of the time during the Obama administration, yet not at all in our subsample spanning the Trump administration. Again, in

${ }^{23}$ This is an especially notable finding given that the passage of the unprecedentedly massive $\$ 2$ trillion COVID-19 stimulus package (in the Spring of 2020) was included in our analysis. 
contrast to Hannity, the results for Maddow are inconsistent with H1. The rate of mentions across the periods on Maddow is statistically indistinguishable from zero in both presidential administrations. Given the results of Figure 5, this latter finding does not mean that Maddow avoids discussing the debt or deficits - rather, the discussion is almost never centered on the incumbent's responsibility for developments in those realms, regardless of which party occupies the presidency.

Taken together, the automated and manual text analyses suggest that on left-leaning cable television, the party of the president has relatively little effect on discourse surrounding the national debt and federal budget deficits. In contrast, right-leaning partisan media transmit explicit responsibility attributions for debt and deficit issues under Democratic presidents, yet this tendency nearly vanishes when a Republican occupies the White House. Our results thus confirm that, like partisans in the mass public, elites operating in partisan mass media also systematically adjust attention to deficits based on the party of the president. However, in this case, we do find a substantial asymmetry in how partisan media communicate about government overspending to the American public, with conservative media more inclined to adjust attention to deficits than liberal media.

\section{DISCUSSION \& CONCLUSION}

Budget deficits are a perennial feature of modern American politics. The budgetary "bottom line" often looms large in the background of major policy debates, with ubiquitous reference to whether the U.S. "can afford" a given expenditure (existing or proposed) without incurring deficits that will further expand the national debt. The growing literature on partisanmotivated reasoning (PMR) suggests that partisans are highly susceptible to misperceiving the 
extent of government overspending, as well as shifting attribution of responsibility for it, depending upon which party occupies the presidency.

We contribute to this literature by examining an alternative means by which partisans can engage in PMR on the issue of government overspending: shifting the importance they assign to the issue itself. We theorized that this process should occur because overspending likely operates more akin to a valence issue than a positional issue. Thus, if partisans are unlikely to change their position on government overspending, we hypothesized that they will satisfy partisan instincts by instead changing the degree to which they regard overspending as an issue that needs to be prioritized and addressed. In other words, our theory of PMR asserts that when it comes to valence issues, partisans can reason around inconvenient realities by adjusting how attentive they are to these issues. Our study therefore contrasts with the large volume of studies which more narrowly examine divergence in partisans' beliefs about whether valence issue conditions have gotten better or worse (e.g., Evans and Pickup 2010).

Our experimental and observational studies help to explain why partisans' attention to budget deficits is not static across presidential administrations. When it advantages partisans to critique their opponents for deficits, PMR elevates attention to the issue. When one's own party occupies the White House, Republicans' and Democrats' attention towards deficits attenuates. An additional contribution of our study, therefore, is empirical support for the notion that partisans change their perceived importance of overspending for both offensive and defensive reasons.

It is worth highlighting that, because there exist several alternative ways for partisans to engage in motivated reasoning, our tests are likely somewhat conservative. Theoretically, partisans could satisfy their need for congenial interpretations of reality without adjusting the importance of government overspending, e.g., by believing the deficit to be smaller than it is reported to be, 
and/or by rationalizing the attribution of blame for deficits to someone (or something) else rather than to their in-party presidents. Such pathways for PMR would, for example, enable partisans to justify growing budget shortfalls under in-party incumbents while allowing the importance of addressing the deficit in the future to remain virtually intact. That our findings show substantial evidence of PMR in perceived issue importance, therefore, underscores the power and flexibility of PMR as a psychological phenomenon in contemporary American politics.

We do wish to caution, however, that while we find that PMR affects perceived importance of overspending, PMR by no means entirely explains these attitudes. In other words, while we observe sizable shifts in perceived importance of overspending, concern about deficits does not ever completely vanish among citizens, regardless of which party controls the presidency. In fact, in some cases (e.g., in the VSG panel data) we found Republicans to be more concerned about the deficit than Democrats regardless of which party held the presidency. However, in the Lucid experimental data, partisan groups were nearly at parity, though Republicans still expressed more concern on average than Democrats, ceteris paribus.

Notably, most of our findings reveal surprisingly symmetrical effects across Republican and Democratic party identifiers. This symmetry is notable given the Republican Party's more overt commitment to fiscal conservatism, and again speaks to the pervasiveness of PMR as a foundational psychological phenomenon. This symmetry also contrasts with the imbalanced patterns of debt and deficit narratives we observed across Republican- and Democratic-leaning media sources. Again, while our experiments show susceptibility to PMR to be roughly symmetrical across the two parties, our media findings are at least suggestive of the possibility that Republicans, despite professing a more consistent ideological commitment to small government 
and fiscal responsibility than Democrats, may be more exposed to cues from partisan elites about the importance of the national debt and budget deficits during outparty administrations.

More broadly, our analyses of partisans in the mass public clearly indicate that citizens' attention towards valence issues is susceptible to PMR. While earlier studies have revealed stark differences in partisans' economic evaluations and their attributions of responsibility for economic conditions, few have shown consistent evidence of motivated issue attention. Our argument may therefore extend to other valence issues that are well-understood by partisans, including that of specific economic indicators (e.g., unemployment, inflation).

Our examinations of media discourse also contribute to recent debates about the sources of bias in citizens' perceptions. In Bisgaard and Slothuus's (2018) recent study, partisan elites are positioned as central drivers in shaping partisans' beliefs about deficits and their consequences. However, when taken together, our results suggest that PMR about overspending can occur even among partisans who have not been exposed to elite framing efforts. Democrats, whose aligned media (in this case represented by Rachel Maddow) rarely mentioned deficits after Trump assumed office, still adjust their perceived importance of deficits (as shown in the observational and experimental analyses). Thus, PMR on the importance of government overspending may be exacerbated by elite cues, but, even in the absence of elite cues, the underlying psychological process still leads partisans to react in predictable ways as presidential incumbency changes hands.

Our findings therefore complicate theories of presidential accountability. With respect to addressing the deficit, it is unsurprising that presidents might opt to "kick the can" instead of resolving shortfalls via unpopular policies such as tax increases or spending cuts. Logically, this willingness to ignore deficits should render presidents more vulnerable to political attacks. Yet if partisans systematically elevate or attenuate the importance they assign to issues, it potentially 
undermines the extent to which presidents need to be concerned with what the public is communicating regarding the extent to which government should, or should not, run deficits to accomplish various policy ends. In the extreme, presidents could (somewhat justifiably) dismiss deficit-related criticisms as biased and insincere, potentially weakening the link between citizens' deficit prioritization and the national policy agenda. Thus, in addition to the attendant politicoeconomic challenges of reducing government deficits, the partisan politicization of government overspending may well serve to further perpetuate the intractability of deficit reduction. 
FIGURE A1: Overspending Across Democratic and Republican Administrations

\section{$\underline{\text { Panel A }}$}

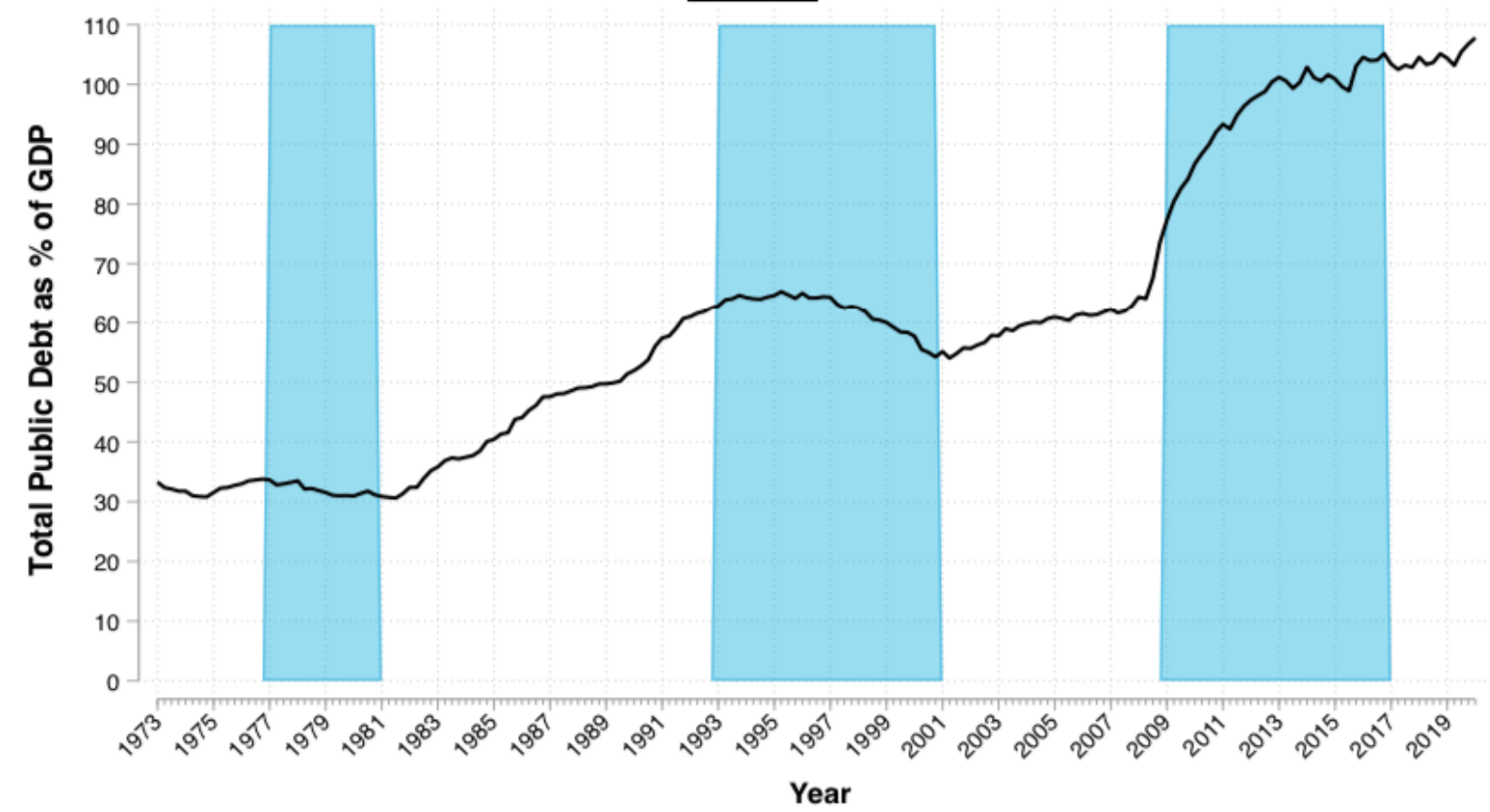

$\underline{\text { Panel B }}$

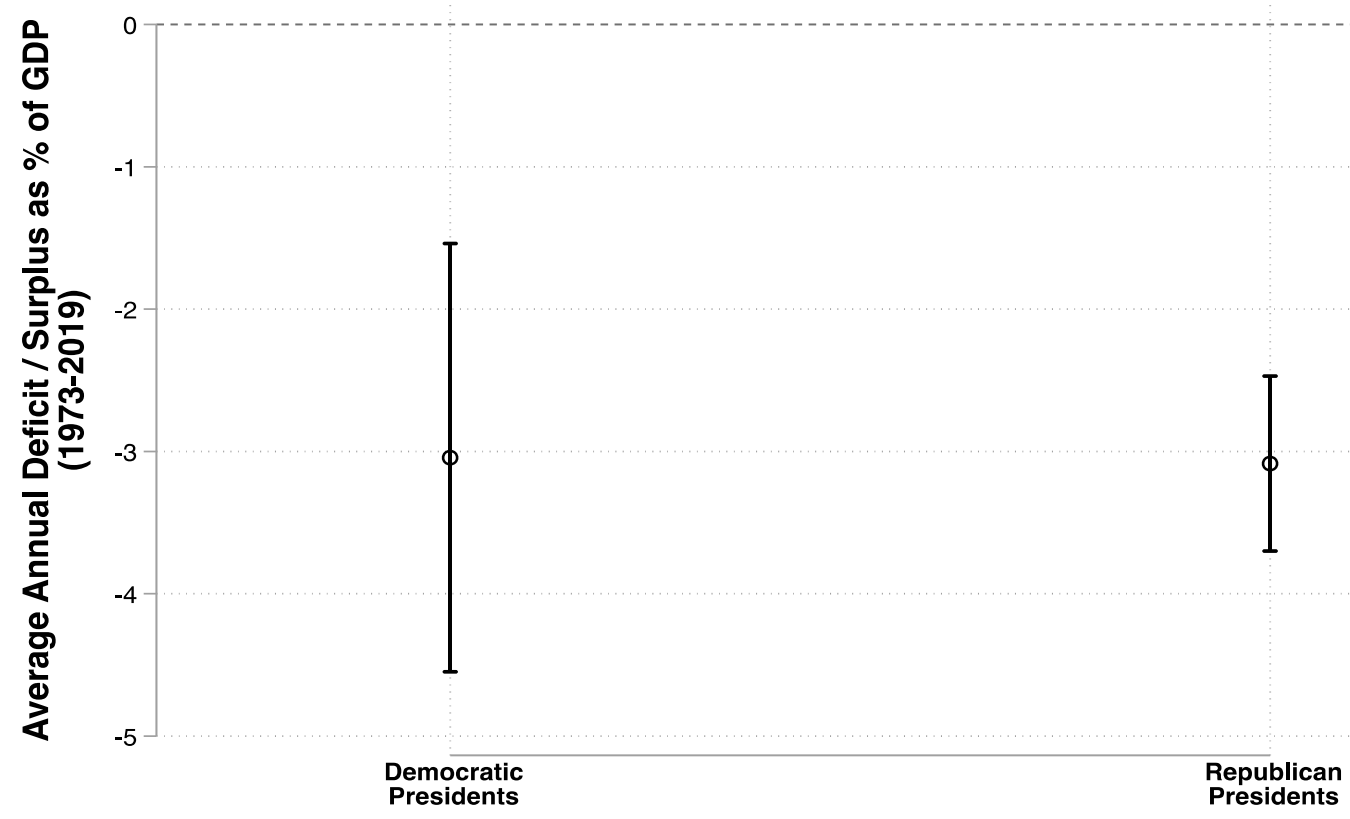

Notes: Panel A shows quarterly total public debt as a share of GDP from 1973 through 2019; shaded regions indicate Democratic presidencies. Panel B shows average annual deficit/surplus as a share of GDP from 1973 through 2019 (Democratic (Republican) mean=-3.09 (-3.04) ( $p=.98$ with SEs clustered by presidency). Data obtained from St. Louis Federal Reserve Economic Data (FRED) 


\section{REFERENCES}

Achen, Christopher H., and Larry M. Bartels. 2016. Democracy for Realists: Why Elections Do Not Produce Responsive Government. Princeton, NJ: Princeton University Press.

Ansolabehere, Stephen, Jonathan Rodden, and James M. Jr. Snyder. 2008. "The Strength of Issues: Using Multiple Measures to Gauge Preference Stability, Ideological Constraint, and Issue Voting." American Political Science Review 102 (02): 215-32.

Ansolabehere, Stephen, and James M. Snyder. 2000. "Valence Politics and Equilibrium in Spatial Election Models." Public Choice 103 (3): 327-36.

Ball, Molly. 2017. "Grover Norquist, the Happiest Man in Washington - The Atlantic." The Atlantic. April 18, 2017. https:/www.theatlantic.com/politics/archive/2017/04/grovernorquist-the-happiest-man-in-washington/523206/.

Barber, Michael, and Jeremy C. Pope. 2019. "Does Party Trump Ideology? Disentangling Party and Ideology in America." American Political Science Review 113 (1): 38-54.

Bartels, Larry M. 2002. "Beyond the Running Tally: Partisan Bias in Political Perceptions." Political Behavior 24 (2): 117-50.

Bisgaard, Martin. 2015. "Bias Will Find a Way: Economic Perceptions, Attributions of Blame, and Partisan-Motivated Reasoning during Crisis." The Journal of Politics 77 (3): 849-60.

- 2019. "How Getting the Facts Right Can Fuel Partisan-Motivated Reasoning." American Journal of Political Science 63 (4): 824-39.

Bisgaard, Martin, and Rune Slothuus. 2018. "Partisan Elites as Culprits? How Party Cues Shape Partisan Perceptual Gaps.” American Journal of Political Science 62 (2): 456-69.

Bolsen, Toby, James N. Druckman, and Fay Lomax Cook. 2014. "The Influence of Partisan Motivated Reasoning on Public Opinion.” Political Behavior 36 (2): 235-62.

Boninger, David S., Jon A. Krosnick, and Matthew K. Berent. 1995. "Origins of Attitude Importance: Self-Interest, Social Identification, and Value Relevance.” Journal of Personality and Social Psychology 68 (1): 61-80.

Boydstun, Amber E. 2013. Making the News: Politics, the Media, and Agenda Setting. Chicago, IL: University of Chicago Press.

Bullock, John G, Alan S Gerber, Seth J Hill, and Gregory A Huber. 2015. "Partisan Bias in Factual Beliefs about Politics.” Quarterly Journal of Political Science 10 (4): 519-78.

Bullock, John G., and Gabriel Lenz. 2019. "Partisan Bias in Surveys." Annual Review of Political Science 22 (1): 325-42. 
Campbell, Angus, Philip E. Converse, Warren E. Miller, and Donald E. Stokes. 1960. The American Voter. Chicago, IL: University of Chicago Press.

Canes-Wrone, Brandice, and Kenneth W. Shotts. 2004. "The Conditional Nature of Presidential Responsiveness to Public Opinion." American Journal of Political Science 48 (4): 690706.

Coe, Kevin, David Tewksbury, Bradley J. Bond, Kristin L. Drogos, Robert W. Porter, Ashley Yahn, and Yuanyuan Zhang. 2008. "Hostile News: Partisan Use and Perceptions of Cable News Programming." Journal of Communication 58 (2): 201-19.

Cohen, Geoffrey L. 2003. "Party Over Policy: The Dominating Impact of Group Influence on Political Beliefs." Journal of Personality and Social Psychology 85 (5): 808-22.

Coppock, Alexander, and Oliver A. McClellan. 2019. "Validating the Demographic, Political, Psychological, and Experimental Results Obtained from a New Source of Online Survey Respondents." Research \& Politics 6 (1): 1-14.

Crosby, Andrew, and Allyson L. Holbrook. 2019. "Public Support for a Balanced Budget Amendment to the U.S. Constitution: Trends and Predictors." Public Budgeting \& Finance 39 (2): 44-67.

Dafoe, Allan, Baobao Zhang, and Devin Caughey. 2018. "Information Equivalence in Survey Experiments." Political Analysis 26 (4): 399-416.

De Geus, Roosmarijn A. 2019. "When Partisan Identification and Economic Evaluations Conflict: A Closer Look at Conflicted Partisans in the United States." Social Science Quarterly 100 (5): $1638-50$.

Dennis, Steven T. 2019. "The Debt Ceiling - Bloomberg." Bloomberg. July 11, 2019. https://www.bloomberg.com/quicktake/the-debt-ceiling.

Desilver, Drew. 2018. "Constitutional Amendments in U.S. Rarely Go Anywhere." Pew Research Center (blog). April 12, 2018. https://www.pewresearch.org/fact-tank/2018/04/12/a-lookat-proposed-constitutional-amendments-and-how-seldom-they-go-anywhere/.

Dickerson, Bradley T., and Heather L. Ondercin. 2017. "Conditional Motivated Reasoning: How the Local Economy Moderates Partisan Motivations in Economic Perceptions.” Political Research Quarterly 70 (1): 194-208.

Evans, Geoffrey, and Mark Pickup. 2010. "Reversing the Causal Arrow: The Political Conditioning of Economic Perceptions in the 2000-2004 U.S. Presidential Election Cycle." The Journal of Politics 72 (04): 1236-51.

Feldman, Stanley. 1988. "Structure and Consistency in Public Opinion: The Role of Core Beliefs and Values." American Journal of Political Science 32 (2): 416. 
Feldman, Stanley, and John Zaller. 1992. "The Political Culture of Ambivalence: Ideological Responses to the Welfare State." American Journal of Political Science 36 (1): 268.

Fisher, Louis. 2012. "Presidential Budgetary Duties.” Presidential Studies Quarterly 42 (4): 75490.

Flynn, D.J., Brendan Nyhan, and Jason Reifler. 2017. "The Nature and Origins of Misperceptions: Understanding False and Unsupported Beliefs About Politics." Political Psychology 38 (February): 127-50.

Gerber, Alan S., and Donald P. Green. 2012. Field Experiments: Design, Analysis, and Interpretation. New York: W. W. Norton \& Company.

Gerber, Alan S., and Gregory A. Huber. 2009. "Partisanship and Economic Behavior: Do Partisan Differences in Economic Forecasts Predict Real Economic Behavior?" American Political Science Review 103 (03): 407-26. https://doi.org/10.1017/S0003055409990098.

Grossmann, Matthew, and David A. Hopkins. 2016. Asymmetric Politics: Ideological Republicans and Group Interest Democrats. New York, NY: Oxford University Press.

Gruszczynski, Mike. 2020. "Evidence of Partisan Agenda Fragmentation in the American Public, 1959-2015." Public Opinion Quarterly. https://academic.oup.com/poq/advancearticle/doi/10.1093/poq/nfz046/5708951.

Heilbroner, Robert L., and Peter L. Bernstein. 1989. The Debt and the Deficit: False Alarms/Real Possibilities. New York, NY: Norton.

Jacobson, Louis. 2015. "PolitiFact | Pie Chart of 'federal Spending' Circulating on the Internet Is Misleading." Politifact. August 2015. https://www.politifact.com/factchecks/2015/aug/17/facebook-posts/pie-chart-federalspending-circulating-internet-mi/.

Jerit, Jennifer, and Jason Barabas. 2012. "Partisan Perceptual Bias and the Information Environment." The Journal of Politics 74 (03): 672-684.

Jones, Bryan D., and Frank R. Baumgartner. 2004. "Representation and Agenda Setting." Policy Studies Journal 32 (1): 1-24.

Jones, Philip Edward. 2019. "Partisanship, Political Awareness, and Retrospective Evaluations, 1956-2016." Political Behavior, March.

Kane, John V. 2016. "Control, Accountability, and Constraints: Rethinking Perceptions of Presidential Responsibility for the Economy.” Presidential Studies Quarterly 46 (2): 33564. 
Kane, John V., and Jason Barabas. 2019. "No Harm in Checking: Using Factual Manipulation Checks to Assess Attentiveness in Experiments." American Journal of Political Science 63 (1): 234-49.

Kessler, Glenn. 2016. “Trump's Nonsensical Claim He Can Eliminate \$19 Trillion in Debt in Eight Years." Washington Post, April 2, 2016. https://www.washingtonpost.com/news/factchecker/wp/2016/04/02/trumps-nonsensical-claim-he-can-eliminate-19-trillion-in-debtin-eight-years/.

Kinder, Donald R., and Nathan P. Kalmoe. 2017. Neither Liberal nor Conservative: Ideological Innocence in the American Public. Chicago, IL: University of Chicago Press.

Kroft, Steve. 2012. "The Pledge: Grover Norquist's Hold on the GOP.” CBS News: 60 Minutes. August 26, 2012. https://www.cbsnews.com/news/the-pledge-grover-norquists-hold-onthe-gop-26-08-2012/.

Krosnick, Jon A. 1990. "Government Policy and Citizen Passion: A Study of Issue Publics in Contemporary America." Political Behavior 12 (1): 59-92.

Krugman, Paul. 2019. "The Legacy of Destructive Austerity." The New York Times. December 30, $2019 . \quad$ https://www.nytimes.com/2019/12/30/opinion/deficitseconomy.html action $=$ click \&module $=$ Opinion $\&$ pgtype $=$ Homepage .

Krugman, Paul R. 2000. The Return of Depression Economics. New York, NY: W. W. Norton \& Company.

Kunda, Ziva. 1990. “The Case for Motivated Reasoning.” Psychological Bulletin 108 (3): 480-98.

Lavine, Howard G., Christopher D. Johnston, and Marco R. Steenbergen. 2012. The Ambivalent Partisan: How Critical Loyalty Promotes Democracy. Oxford University Press.

Leeper, Thomas J., and Rune Slothuus. 2014. "Political Parties, Motivated Reasoning, and Public Opinion Formation." Political Psychology 35 (S1): 129-156.

Levendusky, Matthew. 2013. How Partisan Media Polarize America. University of Chicago Press.

Levitan, Dave. 2019. "The Green New Deal Costs Less Than Doing Nothing." The New Republic, May 3, 2019. https://newrepublic.com/article/153702/green-new-deal-costs-less-nothing.

Lewis-Beck, Michael S., William G. Jacoby, Helmut Norpoth, and Herbert F. Weisberg. 2008. The American Voter Revisited. University of Michigan Press.

Liu, Jodi L., and Christine Eibner. 2019. "National Health Spending Estimates Under Medicare for All:" Product Page. RAND Corporation. https://www.rand.org/pubs/research_reports/RR3106.html. 
Lodge, Milton, and Charles S. Taber. 2013. The Rationalizing Voter. New York, NY: Cambridge University Press.

Mann, Thomas E., and Norman J. Ornstein. 2013. It's Even Worse Than It Looks: How the American Constitutional System Collided With the New Politics of Extremism. Basic Books.

Mason, Lilliana. 2015. “'I Disrespectfully Agree': The Differential Effects of Partisan Sorting on Social and Issue Polarization." American Journal of Political Science 59 (1): 128-45.

Meirick, Patrick C. 2016. "Motivated Reasoning, Accuracy, and Updating in Perceptions of Bush's Legacy.” Social Science Quarterly 97 (3): 699-713.

Morgan, Iwan. 2009. The Age of Deficits: Presidents and Unbalanced Budgets from Jimmy Carter to George W. Bush. Lawrence, Kan: University Press of Kansas.

Mullinix, Kevin J. 2016. "Partisanship and Preference Formation: Competing Motivations, Elite Polarization, and Issue Importance." Political Behavior 38 (2): 383-411.

Newman, Brian. 2013. "Polls and Elections: Decreasing the Economy's Impact on Evaluations of the President: An Experiment on Attribution Framing." Presidential Studies Quarterly 43 (4): 866-82.

Newport, Frank. 2013. "Debt, Gov't Dysfunction Rise to Top of Americans' Issue List." Gallup.Com. January 14, 2013. https://news.gallup.com/poll/159830/debt-govdysfunction-rise-top-americans-issue-list.aspx.

Parker-Stephen, Evan. 2013. "Tides of Disagreement: How Reality Facilitates (and Inhibits) Partisan Public Opinion.” The Journal of Politics 75 (04): 1077-88.।

Pew Research Center. 2016. "Budget Deficit Losing Importance as Public Priority." Pew Research Center for the People and the Press. Pew Research Center - U.S. Politics \& Policy (blog). January 22, 2016. https://www.people-press.org/2016/01/22/budget-deficit-slips-aspublic-priority/.

- 2019. "Public's 2019 Priorities: Economy, Health Care, Education and Security All Near Top of List." Pew Research Center: U.S. Politics \& Policy. https://www.pewresearch.org/politics/2019/01/24/publics-2019-priorities-economyhealth-care-education-and-security-all-near-top-of-list/.

Rudolph, Thomas J. 2003. "Who's Responsible for the Economy? The Formation and Consequences of Responsibility Attributions." American Journal of Political Science 47 (4): 698-713.

— 2006. "Triangulating Political Responsibility: The Motivated Formation of Responsibility Judgments.” Political Psychology 27 (1): 99-122. 
Sirin, Cigdem V., and José D. Villalobos. 2011. "Where Does the Buck Stop? Applying Attribution Theory to Examine Public Appraisals of the President." Presidential Studies Quarterly 41 (2): 334-57.

Slothuus, Rune, and Claes H. de Vreese. 2010. "Political Parties, Motivated Reasoning, and Issue Framing Effects.” The Journal of Politics 72 (3): 630-45.

Smith, Robert. 2011. “When U.S. Paid Off National Debt (Why It Didn't Last).”NPR.Org. August 15, 2011. https://www.npr.org/sections/money/2011/04/15/135423586/when-the-u-spaid-off-the-entire-national-debt-and-why-it-didnt-last.

Stokes, Donald E. 1963. "Spatial Models of Party Competition." American Political Science Review 57 (2): 368-77.

Streeck, Wolfgang, and Armin Schäfer. 2013. Politics in the Age of Austerity. Malden, MA: John Wiley \& Sons.

Tankersley, Jim, Thomas Kaplan, and Alan Rappeport. 2017. "Republican Plan Delivers Permanent Corporate Tax Cut." The New York Times, November 2, 2017, sec. U.S. https://www.nytimes.com/2017/11/02/us/politics/tax-plan-republicans.html.

The New York Times. 2008. "Obama Delivers Speech on Economy." June 9, 2008. https://www.nytimes.com/2008/06/09/us/politics/09transcript-obama.html.

Thomas, Kyle A., and Scott Clifford. 2017. "Validity and Mechanical Turk: An Assessment of Exclusion Methods and Interactive Experiments." Computers in Human Behavior 77 (December): 184-97.

Wood, B. Dan. 2004. "Presidential Rhetoric and Economic Leadership." Presidential Studies Quarterly 34 (3): 573-606. 


\section{SUPPLEMENTAL APPENDIX}

DEFICIT ATTENTION DISORDER:

Partisan-Motivated Reasoning About Government Overspending

TABLE OF CONTENTS

SUPPLEMENTAL APPENDIX A: ETHICAL STATEMENT \& EXPERIMENTAL SAMPLE INFORMATION

SUPPLEMENTAL APPENDIX B: EXPERIMENTAL VIGNETTES \& MEASURES

SUPPLEMENTAL APPENDIX C: MANIPULATION CHECK ANALYSES

SUPPLEMENTAL APPENDIX D: EXPERIMENT REGRESSION OUTPUT

SUPPLEMENTAL APPENDIX E: OBSERVATIONAL REGRESSION OUTPUT \& ALTERNATIVE MODELS

SUPPLEMENTAL APPENDIX F: PARTISAN MEDIA CONTENT ANALYSIS DETAILS 


\section{SUPPLEMENTAL APPENDIX A: ETHICAL STATEMENT \& EXPERIMENTAL SAMPLE INFORMATION}

Experimental subjects were treated in a manner that is consistent with the IRB guidelines of the respective universities under which the protocols were approved. This means that participants were explicitly informed that commencing the survey is indicative of consent to participate, and were remunerated for their time in a way that is consistent with existing research practices and standards for ethical employment practices in the states in which the universities are located. MTurk respondents were compensated in accordance with the [blinded state] minimum wage, which is equivalent to $\$ 11 / \mathrm{hr}$. scaled to the length of the survey. The researchers did not compensate Lucid participants directly but, given the $\$ 1$ fee per respondent, this would amount to roughly $83 \%$ of the federal minimum wage for the 10 minute survey. Table A1 displays descriptive statistics for various demographic and political variables in both of our experimental samples.

\section{TABLE A1. Sample Characteristics of MTurk and Lucid Studies}

\begin{tabular}{lcc}
\hline & $\begin{array}{c}\mathbf{2 0 2 0} \\
\text { MTurk } \\
\text { Sample } \\
(\mathbf{N = 1 , 0 2 4 )}\end{array}$ & $\begin{array}{c}\mathbf{2 0 2 0} \\
\text { Lucid } \\
\text { Sample } \\
(\mathbf{N = 5 , 0 3 4 )}\end{array}$ \\
\hline Median Income & $\$ 40 \mathrm{k}-49 \mathrm{k}$ & $\$ 25 \mathrm{k}-50 \mathrm{k}$ \\
Median Age (SD) & $48(17)$ & $46(17)$ \\
Female & $41.81 \%$ & $44.26 \%$ \\
White & $70.66 \%$ & $74.83 \%$ \\
Black & $11.21 \%$ & $10.43 \%$ \\
Hispanic & $5.75 \%$ & $16.99 \%$ \\
Democrat & $56.15 \%$ & $44.76 \%$ \\
Independent & $14.94 \%$ & $17.68 \%$ \\
Republican & $28.91 \%$ & $37.56 \%$ \\
Liberal & $49.16 \%$ & $34.05 \%$ \\
Moderate & $24.09 \%$ & $31.01 \%$ \\
Conservative & $26.75 \%$ & $34.94 \%$ \\
\hline
\end{tabular}

Note: MTurk and Lucid studies fielded in January and February of 2020, respectively. The Lucid sample was selected to closely mirror U.S. Census data on Age, Race/Ethnicity (White Non-Hispanic; Black NonHispanic; Hispanic; Other), Gender, and Geographic Region (West; Midwest; Northeast; South). 


\section{SUPPLEMENTAL APPENDIX B: \\ EXPERIMENTAL VIGNETTES \& MEASURES}

Experimental Vignette Wording

\section{Introduction}

Now we'd like you to read a brief excerpt from a forthcoming study of government spending over the past 45 years. The study was completed by a variety of professional economists, university researchers, and government analysts.

Please read the information carefully as you will be asked questions about it afterward.

Placebo Condition (Lucid Study Only)

Government Spending and Deficits Under U.S. Presidents: 1973-2018

Every president ran a budget deficit during their time in office, our analysis found. On average, presidents spent around $\mathbf{1 3 . 5 \%}$ more each year than the federal government took in.

Government spending is an issue that we often hear about in the United States. While different presidents have different policy priorities, our analysis of U.S. presidents finds several noteworthy consistencies across the 45-year period of 1973 to 2018 (the most recent year for which we were able to obtain data).

The majority of federal government spending is on social programs and national defense. Presidents, on average, oversaw approximately $75 \%$ of the federal budget being spent on social programs (mainly Social Security, Medicare, and Medicaid, and to a lesser extent other spending on veterans, the poor and the disabled). Approximately $16 \%$ of presidents' budgets were dedicated to defense-related spending.

However, on average, government spending during these presidencies substantially exceeded revenue. In fact, presidents since 1973 spent, on average, 13.5\% more each year than the federal government took in. This means that for every $\$ 100$ that presidents collected in revenue each year, they oversaw $\$ 113.50$ being spent.

With U.S. presidents having consistently run budget deficits over many years, this has resulted in a steady increase in the national debt, which is the total amount of money owed by the federal 
government. Again, we find this pattern of increasing the national debt to be remarkably consistent among U.S. presidents since 1973.

\section{Democratic Presidents Treatment}

\section{Government Spending and Deficits Under Democratic Presidents: 1973-2018}

Every Democratic president ran a budget deficit during their time in office, our analysis found. On average, Democratic presidents spent around $13.5 \%$ more each year than the federal government took in.

Government spending is an issue that we often hear about in the United States. While different presidents have different policy priorities, our analysis of Democratic presidents finds several noteworthy consistencies across the 45-year period of 1973 to 2018 (the most recent year for which we were able to obtain data).

The majority of federal government spending is on social programs and national defense. Democratic presidents, on average, oversaw approximately $75 \%$ of the federal budget being spent on social programs (mainly Social Security, Medicare, and Medicaid, and to a lesser extent other spending on veterans, the poor and the disabled). Approximately $16 \%$ of these presidents' budgets were dedicated to defense-related spending.

However, on average, government spending during these Democratic presidencies substantially exceeded revenue. In fact, Democratic presidents since 1973 spent, on average, 13.5\% more each year than the federal government took in. This means that for every $\$ 100$ that Democratic presidents collected in revenue each year, they oversaw $\$ 113.50$ being spent.

With Democratic presidents having consistently run budget deficits over many years, this has resulted in a steady increase in the national debt, which is the total amount of money owed by the federal government. Again, we find this pattern of increasing the national debt to be remarkably consistent among Democratic presidents since 1973.

Republican Presidents Treatment

Government Spending and Deficits Under Republican Presidents: 1973-2018

Every Republican president ran a budget deficit during their time in office, our analysis found. On average, Republican presidents spent around $13.5 \%$ more each year than the federal government took in.

Government spending is an issue that we often hear about in the United States. While different presidents have different policy priorities, our analysis of Republican presidents finds several noteworthy consistencies across the 45-year period of 1973 to 2018 (the most recent year for which we were able to obtain data).

The majority of federal government spending is on social programs and national defense. Republican presidents, on average, oversaw approximately $75 \%$ of the federal budget being spent on social 
programs (mainly Social Security, Medicare, and Medicaid, and to a lesser extent other spending on veterans, the poor and the disabled). Approximately $16 \%$ of these presidents' budgets were dedicated to defense-related spending.

However, on average, government spending during these Republican presidencies substantially exceeded revenue. In fact, Republican presidents since 1973 spent, on average, $13.5 \%$ more each year than the federal government took in. This means that for every $\$ 100$ that Republican presidents collected in revenue each year, they oversaw $\$ 113.50$ being spent.

With Republican presidents having consistently run budget deficits over many years, this has resulted in a steady increase in the national debt, which is the total amount of money owed by the federal government. Again, we find this pattern of increasing the national debt to be remarkably consistent among Republican presidents since 1973.

Party Identification [Recoded to Democrats/Leaners, Pure Independents, and Republicans/Leaners]

Generally speaking, do you consider yourself to be a(n):

\section{Strong Democrat (1)}

Democrat (2)

Independent, but Leaning Democratic (3)

Independent (4)

Independent, but Leaning Republican (5)

Republican (6)

Strong Republican (7) 
Outcome Measures

1 [reverse coded]. In general, how concerned are you about the federal government running budget deficits?

Very concerned (1)

Somewhat concerned (2)

Not too concerned (3)

Not at all concerned (4)

2. In your opinion, how important is the issue of federal budget deficits?

Not important (1)

Slightly important (2)

Moderately important (3)

Very important (4)

Extremely important (5)

3 [reverse coded]. To what extent should the federal government prioritize reducing the deficit over other policies (such as funding defense and social programs)?

Greatly prioritize the deficit (1)

Somewhat prioritize the deficit (2)

Give little priority to the deficit (3)

Do not prioritize the deficit at all (4)

4 [reverse coded]. Currently, the federal government is running another large budget deficit. In your opinion, how quickly does the federal government need to act in order to reduce the size of the national debt?

Immediately (1)

Very soon (2)

Somewhat soon (3) 
5 [reverse coded]. As you may know, spending on the military and social programs (such as Social Security, Medicare, and Medicaid) account for the vast majority of all federal spending. To reduce the federal budget deficit, to what extent should we cut spending?

A great deal (1)

A lot (2)

A moderate amount (3)

A little (4)

None at all (5)

6 [reverse coded]. Please tell us if you think the following policy should be a top priority, important but lower priority, not too important or that it should not be done:

\section{Reducing the federal budget deficit}

Top Priority (1)

Important but Lower Priority (2)

Not Too Important (3)

Should Not Be Done (4) 
In the article you read, presidents from which political party were discussed [Response options randomized; correct response depends upon treatment assignment]?

Democratic Party (1)

Republican Party (2)

Another Party (3)

No Political Party (4)

According to the article you read, every [Democratic/Republican] president [Response options randomized; highlighted response is the correct response]:

Ran a budget deficit (1)

Ran a budget surplus (2)

Oversaw balanced budgets (3)

Ran more budget surpluses than deficits (4)

According to the article you just read, about how much more (on average) did Republican presidents spend compared to the amount the federal government took in? [Response options randomized; highlighted response is the correct response]

$$
13.5 \%(1)
$$

$90 \%(3)$

$4.5 \%(4)$

$0.1 \%(5)$

Subjective Manipulation Check

Please rate your level of agreement with the following sentence: 
In recent decades, [Democratic/Republican] presidents have run budget deficits and increased the national debt.

Strongly Disagree (1)

Disagree (2)

Somewhat disagree (3)

Neither agree nor disagree (4)

Somewhat agree (5)

Agree (6)

Strongly agree (7) 


\section{SUPPLEMENTAL APPENDIX C: MANIPULATION CHECK ANALYSES}

As noted in the manuscript, our experimental studies featured post-outcome manipulation checks. Specifically, both studies featured treatment-relevant and treatment-irrelevant factual manipulation checks (FMC-TR and FMC-TI, respectively) (see Kane \& Barabas 2019). In addition, the Lucid study featured a subjective manipulation check (SMC; see Kane and Barabas 2019).

The FMC-TR results are displayed in Table $\mathrm{C} 1$. These results confirm that the party of the president mentioned in the article was accurately perceived by a vast majority of respondents, and that these perceptions significantly covary with treatment assignment. Finding this pattern is crucial given that the experimental manipulation is simply the party of the presidents featured in the article.

\section{TABLE C1: Treatment-Relevant Factual Manipulation Check (Party Mentioned) Results}

\begin{tabular}{|c|c|c|c|c|c|c|}
\hline & \multicolumn{6}{|c|}{ MTurk Study } \\
\hline & \multicolumn{2}{|c|}{ Democrats } & \multicolumn{2}{|c|}{ Republicans } & \multicolumn{2}{|c|}{ Independents } \\
\hline & $\begin{array}{l}\text { Presidents } \\
(R)\end{array}$ & $\begin{array}{c}\text { Presidents } \\
\text { (D) }\end{array}$ & $\begin{array}{c}\text { Presidents } \\
(R)\end{array}$ & $\begin{array}{l}\text { Presidents } \\
\text { (D) }\end{array}$ & $\begin{array}{l}\text { Presidents } \\
(R)\end{array}$ & $\begin{array}{l}\text { Presidents } \\
\text { (D) }\end{array}$ \\
\hline \multicolumn{7}{|c|}{ Party Mentioned } \\
\hline Democratic & $10.58 \%$ & $93.97 \%$ & $2.04 \%$ & $\mathbf{7 7 . 1 8 \%}$ & $5.63 \%$ & $81.71 \%$ \\
\hline Republican & $\mathbf{8 6 . 0 1 \%}$ & $2.48 \%$ & $95.24 \%$ & $19.46 \%$ & $88.73 \%$ & $13.41 \%$ \\
\hline Other & $2.05 \%$ & $1.42 \%$ & $2.04 \%$ & $0.00 \%$ & $2.82 \%$ & $2.44 \%$ \\
\hline No Party & $1.37 \%$ & $2.13 \%$ & $0.68 \%$ & $3.36 \%$ & $2.82 \%$ & $2.44 \%$ \\
\hline \multirow[t]{4}{*}{$\chi^{2} \mathrm{p}$-value } & \multicolumn{2}{|c|}{$<.001$} & \multicolumn{2}{|c|}{$<.001$} & \multicolumn{2}{|c|}{$<.001$} \\
\hline & \multicolumn{6}{|c|}{ Lucid Study } \\
\hline & \multicolumn{2}{|c|}{ Democrats } & \multicolumn{2}{|c|}{ Republicans } & \multicolumn{2}{|c|}{ Independents } \\
\hline & $\begin{array}{c}\text { Presidents } \\
(R)\end{array}$ & $\begin{array}{c}\text { Presidents } \\
\text { (D) }\end{array}$ & $\begin{array}{c}\text { Presidents } \\
(R)\end{array}$ & $\begin{array}{c}\text { Presidents } \\
(D)\end{array}$ & $\begin{array}{l}\text { Presidents } \\
(R)\end{array}$ & $\begin{array}{c}\text { Presidents } \\
\text { (D) }\end{array}$ \\
\hline \multicolumn{7}{|c|}{ Party Mentioned } \\
\hline Democratic & $11.54 \%$ & $82.23 \%$ & $2.81 \%$ & $78.44 \%$ & $4.36 \%$ & $69.37 \%$ \\
\hline Republican & $79.27 \%$ & $5.33 \%$ & $89.76 \%$ & $14.04 \%$ & $75.08 \%$ & $6.31 \%$ \\
\hline Other & $3.89 \%$ & $3.67 \%$ & $2.52 \%$ & $2.55 \%$ & $7.48 \%$ & $7.51 \%$ \\
\hline No Party & $5.3 \%$ & $8.77 \%$ & $4.96 \%$ & $4.96 \%$ & $13.08 \%$ & $16.82 \%$ \\
\hline$\chi^{2} \mathrm{p}$-value & \multicolumn{2}{|c|}{$<.001$} & \multicolumn{2}{|c|}{$<.001$} & \multicolumn{2}{|c|}{$<.001$} \\
\hline
\end{tabular}

Notes: Figures indicate the \% giving a particular response to the question of, "In the article you read, presidents from which political party were discussed?" across the two key experimental conditions (by partisan identification). Bolded percentages indicate the share answering correctly. 
The FMC-TI results are displayed in Table $\mathrm{C} 2$. These results confirm that large majorities of respondents were attentive to key (non-manipulated) information in each article - namely, that (1) presidents of a given party (Republican or Democratic) were described as having run budget deficits, and (2) that, on average, presidents of a given party oversaw spending that was about $13.5 \%$ higher than what the federal government took in via revenues.

\section{TABLE C2: Treatment-Irrelevant Factual Manipulation Checks}

\begin{tabular}{|c|c|c|c|c|c|c|}
\hline & \multicolumn{2}{|c|}{ Democrats } & \multicolumn{2}{|c|}{ Republicans } & \multicolumn{2}{|c|}{ Independents } \\
\hline & $\begin{array}{l}\text { Presidents } \\
(R)\end{array}$ & $\begin{array}{l}\text { Presidents } \\
\text { (D) }\end{array}$ & $\begin{array}{l}\text { Presidents } \\
(R)\end{array}$ & $\begin{array}{l}\text { Presidents } \\
\text { (D) }\end{array}$ & $\begin{array}{l}\text { Presidents } \\
(R)\end{array}$ & $\begin{array}{l}\text { Presidents } \\
\text { (D) }\end{array}$ \\
\hline Question & $\begin{array}{l}\text { "According } \\
\text { president.. }\end{array}$ & to the & cle you re & d, every & Republican & [c] \\
\hline $\begin{array}{c}\% \text { Answering } \\
\text { Correctly (MTurk) }\end{array}$ & $85.67 \%$ & $86.17 \%$ & $82.99 \%$ & $80.54 \%$ & $85.92 \%$ & $84.15 \%$ \\
\hline $\begin{array}{c}\% \text { Answering } \\
\text { Correctly (Lucid) }\end{array}$ & $78.68 \%$ & $72.72 \%$ & $76.72 \%$ & $79.01 \%$ & $73.21 \%$ & $74.17 \%$ \\
\hline Ques & $\begin{array}{l}\text { "According } \\
\text { did [Repub } \\
\text { federal gov }\end{array}$ & $\begin{array}{l}\text { to the article } \\
\text { ican/Democ } \\
\text { rnment took }\end{array}$ & $\begin{array}{l}\text { you just rea } \\
\text { tic] preside } \\
\text { in?" }\end{array}$ & $\begin{array}{l}\text {, about how } \\
\text { ts spend con }\end{array}$ & $\begin{array}{l}\text { much more } \\
\text { apared to the }\end{array}$ & $\begin{array}{l}\text { on average) } \\
\text { amount the }\end{array}$ \\
\hline $\begin{array}{c}\% \text { Answering } \\
\text { Correctly (MTurk) } \\
\% \text { Answering }\end{array}$ & $86.69 \%$ & $88.30 \%$ & $82.99 \%$ & $79.87 \%$ & $84.51 \%$ & $86.59 \%$ \\
\hline Correctly (Lucid) & $78.21 \%$ & $78.79 \%$ & $78.54 \%$ & $80.85 \%$ & $76.01 \%$ & $78.08 \%$ \\
\hline
\end{tabular}

Notes: Figures indicate the \% giving a particular response to (1) the question of, "According to the article you read, every [Republican/Democratic] president..." with the correct answer being "Ran a budget deficit.", and (2) the question of, "According to the article you just read, about how much more (on average) did Republican presidents spend compared to the amount the federal government took in?" with the correct answer being "13.5\%". Results are shown by partisan group across the two key experimental conditions, separated by study (MTurk or Lucid). 
The results for the SMC are featured in Table $\mathrm{C} 3$. These analyses reveal that, as intended, treatment assignment affected perceptions of whether presidents of a given party (Democratic or Republican) have indeed presided over deficit spending. These significant effects (approximately $1 \mathrm{pt}$. on the 7-point agreement scale) were observed for both partisan groups in our Lucid sample, and occurred for perceptions of both Democratic and Republican presidents. These findings serve to confirm that perceptions of parties' performance were indeed affected by the manipulation.

TABLE C3: Subjective Manipulation Check (Lucid)

\begin{tabular}{|c|c|c|c|c|}
\hline \multirow[b]{2}{*}{ Rating For... } & \multicolumn{2}{|c|}{ Democrats } & \multicolumn{2}{|c|}{ Republicans } \\
\hline & $\begin{array}{c}\text { Democratic } \\
\text { Presidents }\end{array}$ & $\begin{array}{l}\text { Republican } \\
\text { Presidents }\end{array}$ & $\begin{array}{l}\text { Democratic } \\
\text { Presidents }\end{array}$ & $\begin{array}{l}\text { Republican } \\
\text { Presidents }\end{array}$ \\
\hline Party in Treatn & & & & \\
\hline Democratic & 4.48 & 5.07 & 5.86 & 3.94 \\
\hline Republican & 3.34 & 5.83 & 4.99 & 4.89 \\
\hline Difference & +1.14 & -.76 & +.87 & -.96 \\
\hline p-value & $<.001$ & $<.001$ & $<.001$ & $<.001$ \\
\hline
\end{tabular}

Notes: Respondents for their level of agreement with the following statement: "In recent decades, [Democratic/Republican] presidents have run budget deficits and increased the national debt." Responses ranged from "Strongly Disagree" (1) to "Strongly Agree" (7). Columns indicate rating of each party's presidents, disaggregated by partisan group (Democrats and Republicans). Results show that, among both Democratic and Republican respondents, assignment to article about Democratic vs. Republican presidents significantly affected perception that presidents of a given party were responsible for overspending. 


\section{SUPPLEMENTAL APPENDIX D: EXPERIMENT REGRESSION OUTPUT}

TABLE D1: Regression Output for MTurk \& Lucid Experiments

\begin{tabular}{|c|c|c|c|c|}
\hline & \multicolumn{4}{|c|}{ MTurk Study } \\
\hline & All Partisans & Democrats & Republicans & Independents \\
\hline \multicolumn{5}{|l|}{ Party Mentioned } \\
\hline \multirow[t]{2}{*}{ Outparty Presidents } & $0.05 * * *$ & $0.06 * * *$ & $0.05^{*}$ & -0.01 \\
\hline & $(0.01)$ & $(0.02)$ & $(0.02)$ & $(0.03)$ \\
\hline \multirow[t]{2}{*}{ Constant } & $0.58 * * *$ & $0.56 * * *$ & $0.64 * * *$ & $0.65 * * *$ \\
\hline & $(0.01)$ & $(0.01)$ & $(0.01)$ & $(0.02)$ \\
\hline \multirow[t]{2}{*}{$\mathrm{N}$} & 871 & 575 & 296 & 153 \\
\hline & \multicolumn{4}{|c|}{ Lucid Study } \\
\hline & All Partisans & Democrats & Republicans & Independents \\
\hline \multicolumn{5}{|l|}{ Party Mentioned } \\
\hline \multirow[t]{2}{*}{ Placebo Control } & 0.02 & 0.01 & 0.02 & 0.02 \\
\hline & $(0.01)$ & $(0.02)$ & $(0.02)$ & $(0.02)$ \\
\hline \multirow[t]{2}{*}{ Inparty President } & $-0.03 * * *$ & $-0.03 *$ & $-0.03 *$ & 0.00 \\
\hline & $(0.01)$ & $(0.01)$ & $(0.01)$ & $(0.02)$ \\
\hline \multirow[t]{2}{*}{ Outparty President } & $0.04 * * *$ & $0.03^{*}$ & $0.04 * *$ & 0.01 \\
\hline & $(0.01)$ & $(0.01)$ & $(0.01)$ & $(0.02)$ \\
\hline \multirow[t]{2}{*}{ Constant } & $0.67 * * *$ & $0.65 * * *$ & $0.68 * * *$ & $0.64 * * *$ \\
\hline & $(0.01)$ & $(0.01)$ & $(0.01)$ & $(0.02)$ \\
\hline $\mathrm{N}$ & 4144 & 2253 & 1891 & 890 \\
\hline
\end{tabular}


TABLE D2: Interaction Between Outparty (vs. Inparty) President \& Partisan Identity Strength

\begin{tabular}{lcc}
\hline & MTurk Study & Lucid Study \\
\hline \multirow{2}{*}{ Outparty Presidents } & 0.01 & $0.04 * * *$ \\
PID Strength & $(0.02)$ & $(0.01)$ \\
& $-0.04 * *$ & 0.01 \\
Outparty Presidents X PID Strength & $(0.01)$ & $(0.01)$ \\
& $0.04 *$ & $0.02^{*}$ \\
& $(0.02)$ & $(0.01)$ \\
Constant & $0.62 * * *$ & $0.63 * * *$ \\
& $(0.02)$ & $(0.01)$ \\
N & 871 & 3111 \\
\hline OLS coefficients with SEs in parentheses. "Outparty Presidents" is coded as 1 (0) for Outparty (Inparty) \\
ents treatment. Models include partisans only. "PID Strength" is coded as leaner=0, partisan=1, strong
\end{tabular}




\section{SUPPLEMENTAL APPENDIX E: \\ OBSERVATIONAL REGRESSION OUTPUT \& ALTERNATIVE MODELS}

TABLE E1: Binomial and Ordered Logistic Regression Model Output (PRC Data)

\begin{tabular}{|c|c|c|}
\hline & Binomial Model & Ordered Model \\
\hline Independent & $\begin{array}{c}0.21 \\
(0.26)\end{array}$ & $\begin{array}{c}0.26 \\
(0.24)\end{array}$ \\
\hline Republican & $\begin{array}{l}0.87 * * * \\
(0.17)\end{array}$ & $\begin{array}{l}0.84 * * * \\
(0.16)\end{array}$ \\
\hline Trump Administration & $\begin{array}{c}0.01 \\
(0.15)\end{array}$ & $\begin{array}{l}-0.02 \\
(0.14)\end{array}$ \\
\hline Independent $X$ Trump Administration & $\begin{array}{l}-0.10 \\
(0.40)\end{array}$ & $\begin{array}{l}-0.24 \\
(0.38)\end{array}$ \\
\hline Republican X Trump Administration & $\begin{array}{l}-0.55^{*} \\
(0.23)\end{array}$ & $\begin{array}{l}-0.51 * \\
(0.22)\end{array}$ \\
\hline Age & $\begin{array}{c}0.00 \\
(0.00)\end{array}$ & $\begin{array}{c}0.00 \\
(0.00)\end{array}$ \\
\hline Income & $\begin{array}{c}0.01 \\
(0.02)\end{array}$ & $\begin{array}{c}0.01 \\
(0.02)\end{array}$ \\
\hline African-American & $\begin{array}{l}0.52^{* *} \\
(0.19)\end{array}$ & $\begin{array}{l}0.43^{*} \\
(0.19)\end{array}$ \\
\hline Asian & $\begin{array}{c}0.31 \\
(0.32)\end{array}$ & $\begin{array}{c}0.41 \\
(0.30)\end{array}$ \\
\hline Mixed Race & $\begin{array}{c}0.15 \\
(0.28)\end{array}$ & $\begin{array}{c}0.26 \\
(0.26)\end{array}$ \\
\hline Other Race & $\begin{array}{l}-0.36^{\dagger} \\
(0.22)\end{array}$ & $\begin{array}{l}-0.37^{\dagger} \\
(0.20)\end{array}$ \\
\hline Female & $\begin{array}{l}-0.22 * \\
(0.11)\end{array}$ & $\begin{array}{l}-0.17 \\
(0.10)\end{array}$ \\
\hline Education & $\begin{array}{l}-0.12 * * * \\
(0.03)\end{array}$ & $\begin{array}{l}-0.11 * * * \\
(0.03)\end{array}$ \\
\hline Ideology & $\begin{array}{l}0.32 * * * \\
(0.06)\end{array}$ & $\begin{array}{l}0.34 * * * \\
(0.06)\end{array}$ \\
\hline cut1 & -- & $\begin{array}{l}-3.21 * * * \\
(0.33)\end{array}$ \\
\hline cut 2 & -- & $\begin{array}{l}-1.52 * * * \\
(0.30)\end{array}$ \\
\hline cut3 & -- & $\begin{array}{l}-1.26^{* * *} \\
(0.29)\end{array}$ \\
\hline cut4 & -- & $\begin{array}{l}0.75^{* *} \\
(0.29)\end{array}$ \\
\hline Constant & $\begin{array}{l}-0.68^{*} \\
(0.31)\end{array}$ & -- \\
\hline $\begin{array}{l}\mathrm{N} \\
\text { Pseudo-R } \\
\end{array}$ & $\begin{array}{c}1,545 \\
.07 \\
\end{array}$ & $\begin{array}{c}1,545 \\
.05\end{array}$ \\
\hline
\end{tabular}

Notes: Logistic regression coefficients with SEs in parentheses. Dependent variable asks respondents about the importance of "reducing the budget deficit" on a 5-point scale ranging from $1=$ "should not be done" to $5=$ "top 
priority" ("Don't Know" ( $n=51)$ is coded as 3). Binomial model recodes dependent variable to 1= "top priority" and 0 otherwise. Democratic party identification, Obama Administration, and white racial identification are the excluded categories. "Ideology" ranges from liberal to conservative. Data are from January of 2016 and January of 2018 (collected by Pew Research Center). *** $\mathrm{p}<0.001,{ }^{* *} \mathrm{p}<0.01,{ }^{*} \mathrm{p}<0.05, \dagger \mathrm{p}<0.10$.

TABLE E2: Binomial and Ordered Logistic Regression Model Output (VSG Panel Data)

\begin{tabular}{|c|c|c|}
\hline & Binomial Model & Ordered Model \\
\hline Independent & $\begin{array}{l}1.23 * * * \\
(0.07)\end{array}$ & $\begin{array}{l}1.26 * * * \\
(0.07)\end{array}$ \\
\hline Republican & $\begin{array}{l}1.86^{* * * *} \\
(0.05)\end{array}$ & $\begin{array}{l}1.96^{* * * *} \\
(0.05)\end{array}$ \\
\hline 2017 & $\begin{array}{l}-0.02 \\
(0.04)\end{array}$ & $\begin{array}{c}0.01 \\
(0.03)\end{array}$ \\
\hline 2019 & $\begin{array}{l}0.51 * * * \\
(0.04)\end{array}$ & $\begin{array}{l}0.58 * * * \\
(0.04)\end{array}$ \\
\hline Independent X 2017 & $\begin{array}{l}-0.14^{\dagger} \\
(0.08)\end{array}$ & $\begin{array}{l}-0.15^{*} \\
(0.07)\end{array}$ \\
\hline Independent X 2019 & $\begin{array}{l}-0.67 * * * \\
(0.08)\end{array}$ & $\begin{array}{l}-0.71 * * * \\
(0.08)\end{array}$ \\
\hline Republican X 2017 & $\begin{array}{l}-0.13^{*} \\
(0.06)\end{array}$ & $\begin{array}{l}-0.15^{* *} \\
(0.06)\end{array}$ \\
\hline Republican X 2019 & $\begin{array}{c}-1.11 * * * \\
(0.06)\end{array}$ & $\begin{array}{c}-1.15 * * * \\
(0.06)\end{array}$ \\
\hline cutl & -- & $\begin{array}{l}-2.68 * * * \\
(0.06)\end{array}$ \\
\hline cut2 & -- & $\begin{array}{c}-1.01 * * * \\
(0.04)\end{array}$ \\
\hline cut3 & -- & $\begin{array}{l}0.92 * * * \\
(0.03)\end{array}$ \\
\hline Constant & $\begin{array}{l}-0.85 * * * \\
(0.04)\end{array}$ & -- \\
\hline $\begin{array}{l}\mathrm{N} \\
\text { Pseudo-R }{ }^{2}\end{array}$ & $\begin{array}{c}19,559 \\
.09\end{array}$ & $\begin{array}{c}19,559 \\
.07\end{array}$ \\
\hline
\end{tabular}

Notes: Logistic regression coefficients with SEs (in parentheses) clustered by respondent. Dependent variable asks respondents about the importance of "the budget deficit" on a 4-point scale ranging from $1=$ "unimportant" to $5=$ "very important". Binomial model recodes dependent variable to $1=$ "very important" and 0 otherwise. Democratic party identification and Obama Administration (2016) are the excluded categories. Data collected by Voter Study Group across three time points $\left(2016,2017\right.$, and 2019). ${ }^{* * *} \mathrm{p}<0.001,{ }^{* *} \mathrm{p}<0.01,{ }^{*} \mathrm{p}<0.05, \dagger \mathrm{p}<0.10$. 


\section{SUPPLEMENTAL APPENDIX F: PARTISAN MEDIA CONTENT ANALYSIS DETAILS}

\section{Description of Sample}

Transcripts from MSNBC's The Rachel Maddow Show and FOX News' Hannity were collected from the Nexis Uni (formerly LexisNexis) database. These files reflect full-text transcripts of television shows, including host discussion, guest discussion, voiceovers, and any other spoken words. They do not include commercials, still image text, scrolling marquees, or audio from video clips played during the broadcast.

Our search of this database was limited to the beginning of the Obama administration (January 3, 2009) through the Spring of 2020. When sampling the database we sought to include as many unique transcripts across as many air dates as possible in this time period. While this search yields many transcripts, the search function in Nexis Uni is not without flaws, nor is this sample completely balanced over time. We encountered some duplicates and some transcripts of other shows on the respective networks; these were filtered out using the metadata described below.

Figure F1 shows the distributions of the transcripts over time. While Hannity is a relatively longrunning show, and therefore has the appealing property of having relatively complete coverage over the time period, our Maddow transcripts are sparse in 2009. Nevertheless, these two shows give us a large amount of content from the same hosts over two presidencies, allowing for a test of the present hypothesis.

\section{FIGURE F1. A Comparison of Maddow and Hannity Transcripts Over Time}

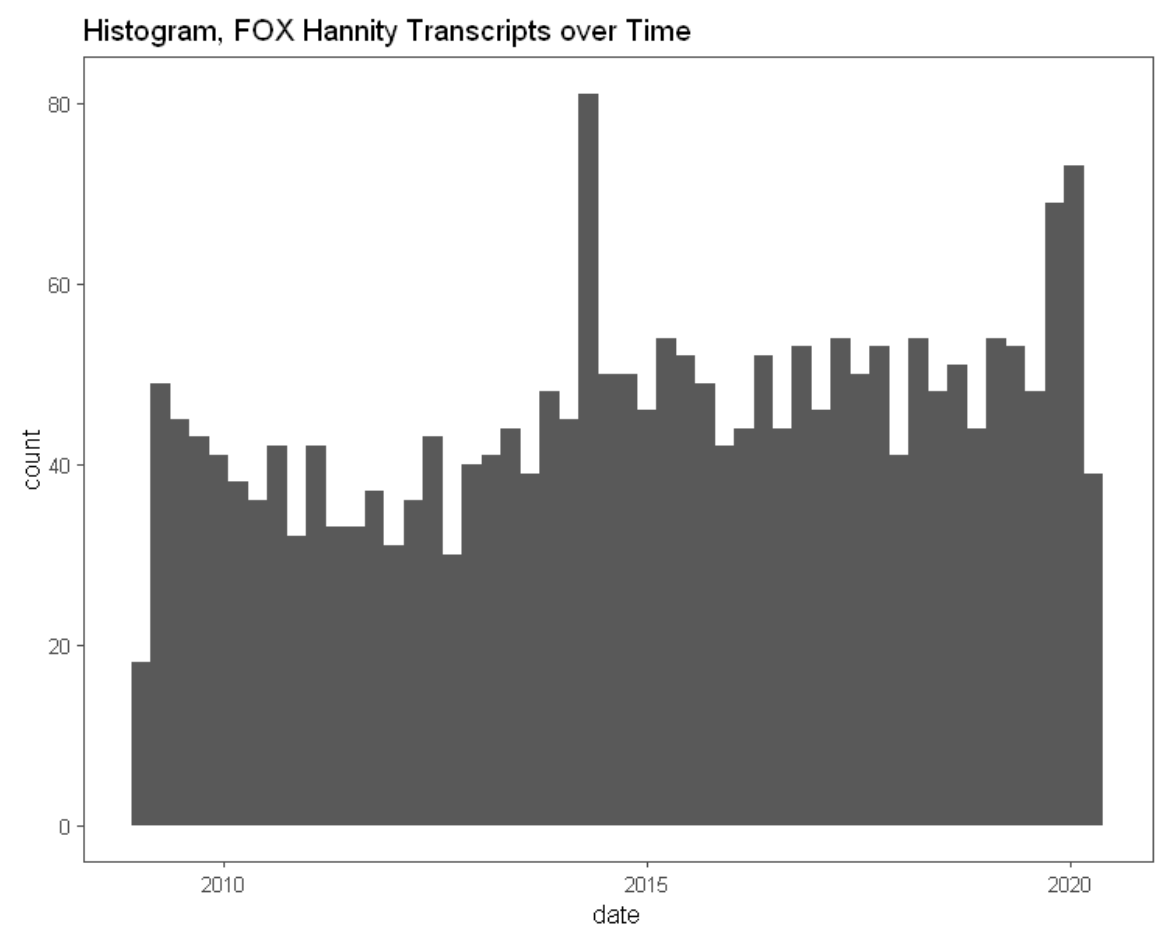




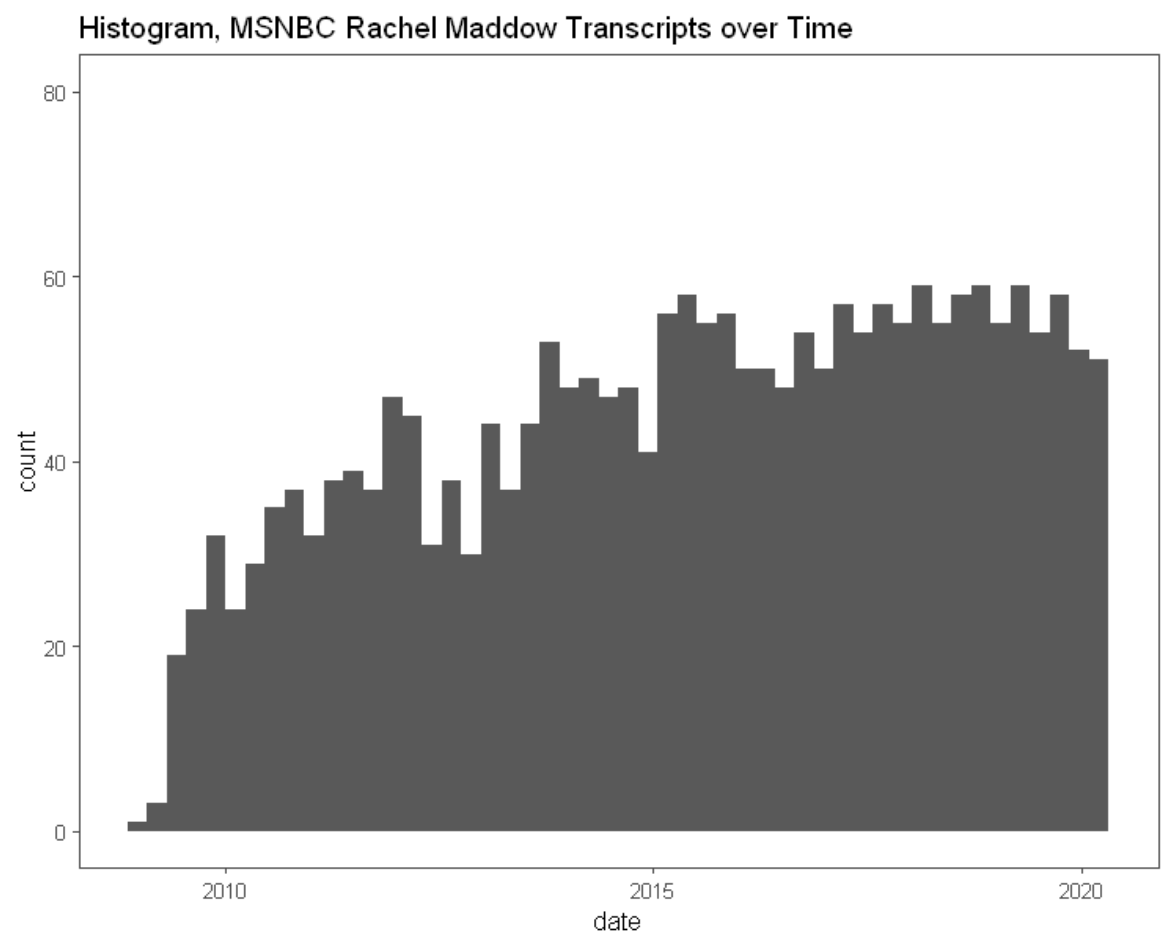

\section{Methodology: Automated Content Analysis}

Content analysis was performed using the $t m$ library in R (Version 3.5.1). The content analytical methodology relied on a simple keyword search. After preprocessing (see below for details), texts were analyzed to determine the occurrence of several exact terms. We sought to capture mentions of budget deficits and the national debt with as broad a set of terms as possible, before identifying false positives in early testing and eliminating them. The $\mathrm{N}$-grams we used to measure mentions was as follows:

\section{Deficit \\ Deficits \\ Debt}

We then sought to exclude N-gram mentions that were made in service of non-debt and nondeficit-related discussions. Because our keywords could be used in other ways, we sought to excise any mentions that used the following linguistic conventions:

\section{Deficit In}

Deficits In

Trade Deficit

Personal Debt

Student Debt

Loan Debt

Debt of Gratitude

His Debt 
Her Debt

Their Debt

A Debt

Debt Relief

Have Debt

Blood Debt

This list of excluded N-grams substantially improves our ability to recognize real mentions of budget deficits. As we will see below in Section X.4, we achieve a high rate of correct identification of budget deficit and national debt mentions. What's more, our broad search terms mean we are also unlikely to miss mentions.

\section{Text Pre-Processing and Metadata Collection}

Texts were ingested as Microsoft .docx files and analyzed as plain text. Metadata about each file were collected and tabularized by relying on the file structure of each Nexis Uni transcript. Different lines of the transcripts contain different pieces of metadata; for example, the show title is always listed on one line, and the date of the transcript is always listed on another.

The body of each text was also analyzed and filtered, in order to arrive at a more precise estimate of Hannity and Maddow's statements about the debt and the deficit. Relying upon the fact that each transcript includes each speaker's name in all caps followed by a colon, we were able to write a regular expression that identified text chunks between each new speaker. Having tagged the text as Maddow/Hannity spoken text and "other speaker" text, we next filtered out all lines without the Maddow/Hannity tag. This reduced the size of the overall corpus substantially, but we were left with only statements spoken on air by the respective speakers.

\section{Automated Content Analysis Validation}

One important task for any content analysis is validation. Our simple lexical identification task was validated using a hand-coded sample of 50 texts. Each text was manually read for any and all mentions of the deficit and the national debt - whether those mentions were included in our dataset or not. For each transcript we checked these manually identified mentions against those included in the automated sample. The result is a confusion matrix, which charts the false positive and false negative error rate. As seen below in Table F1, this confusion matrix reports the accuracy of the classifier. 
TABLE F1. Confusion Matrix, Automated Content Analysis Validation Test

\begin{tabular}{lll}
\hline Deficit & Count & Percentage \\
\hline True Pos: & 29 & \\
Auto Pos: & 28 & \\
False Pos: & 1 & 0.03 \\
False Neg: & 2 & 0.07 \\
& & \\
Debt & Count & Percentage \\
\hline True Pos: & 39 & \\
Auto Pos: & 36 & \\
False Pos: & 2 & 0.05 \\
False Neg: & 5 & 0.13 \\
\hline
\end{tabular}

Hand-Coded Sample: Details and Validation

The hand-coded sample was collected as a random sample of the broader transcript dataset described above. This sample included 200 texts, and was subdivided into Maddow (50\%) and Hannity (50\%) transcripts. The sample was further subdivided into Obama-era and Trump-era transcripts, resulting in four groups for comparison: Maddow/Obama, Maddow/Trump, Hannity/Obama, and Hannity/Trump.

Coders were trained to use the "find" tool in Microsoft Word to identify instances in the (lengthy) transcripts of the terms "debt" and "deficit". Once those terms had been located, coders read the context surrounding the instance to determine:

1. Whether Hannity [Maddow] was the speaker in the instance

2. If so, whether this explicit reference was made in service of a negative valence mention of the debt or the deficit

3. If so, whether the host made an explicit reference to the incumbent president

If criteria 1 and 2 were satisfied, but not criterion 3, the coder would increase the count of "debt/deficit mentions" in a worksheet. If all criteria were positively determined, the coder would increase "debt/deficit mentions" and the count of "responsibility" mentions in the worksheet. These "responsibility" mention counts therefore only include those which are made explicitly in service of the statement that the incumbent has had a negative effect (or at least did not remedy) the debt/deficit—i.e., that the incumbent president is responsible for the deficit/debt.

A comparison of the coders' efforts revealed a Cohen's Kappa of 0.91 for the identification of "debt/deficit mentions", as well as a Cohen's Kappa of 0.82 for "responsibility" mentions. These statistics indicate that the coders' accuracy in identifying mentions and attributions of responsibility were acceptable for the present purposes. 